\title{
Does the short-term fluctuation of mineral element concentrations in the closed hydroponic experimental facilities affect the mineral concentrations in cucumber plants exposed to elevated $\mathrm{CO}_{2}$ ?
}

\author{
Xun Li • Jinlong Dong • Nazim Gruda $\cdot$ Wenying \\ Chu $\cdot$ Zengqiang Duan \\ Received: 5 September 2020 / Accepted: 14 February 2021 / Published online: 14 May 2021 \\ (C) The Author(s) 2021, corrected publication 2021
}

\begin{abstract}
Aims Studies dealing with plants' mineral nutrient status under elevated atmospheric $\mathrm{CO}_{2}$ concentration $\left(\mathrm{eCO}_{2}\right)$ are usually conducted in closed hydroponic systems, in which nutrient solutions are entirely renewed every several days. Here, we investigated the contribution of the fluctuation of concentrations of $\mathrm{N}$ ([N]), $\mathrm{P}([\mathrm{P}])$, and $\mathrm{K}([\mathrm{K}])$ in nutrient solutions in this short period on their concentrations in cucumber plants exposed to different $\left[\mathrm{CO}_{2}\right]$ and $\mathrm{N}$ levels.

Methods Cucumber (Cucumis sativus L.) plants were hydroponically grown under two $\left[\mathrm{CO}_{2}\right]$ and three $\mathrm{N}$ levels. $[\mathrm{N}],[\mathrm{P}]$, and $[\mathrm{K}]$ in nutrient solutions and cucumber plants were analyzed.

Results The transpiration rate (Tr) was significantly inhibited by $\mathrm{eCO}_{2}$, whereas $\mathrm{Tr}$ per plant was increased due to the larger leaf area. Elevated $\left[\mathrm{CO}_{2}\right]$ significantly decreased $[\mathrm{N}]$ in low $\mathrm{N}$ nutrient solutions, which imposed an additional decrease in $[\mathrm{N}]$ in plants. $[\mathrm{P}]$ in nutrient solutions fluctuated slightly, so the change of $[\mathrm{P}]$ in plants might be attributed to the dilution effect and the demand change under $\mathrm{eCO}_{2}$. $[\mathrm{K}]$ in moderate and
\end{abstract}

Responsible Editor: Richard J. Simpson.

X. Li · J. Dong $\cdot$ N. Gruda $\cdot$ W. Chu $\cdot$ Z. Duan $(\bowtie)$

State Key Laboratory of Soil and Sustainable Agriculture, Institute of Soil Science, Chinese Academy of Sciences, Nanjing 210008, People's Republic of China

e-mail: zqduan@issas.ac.cn

N. Gruda $(\bowtie)$

Department of Horticultural Sciences, Institute of Crop Science and Resource Conservation, University of Bonn, 53121 Bonn, high $\mathrm{N}$ nutrient solutions were significantly decreased, which exacerbated the $[\mathrm{K}]$ decrease in plants under $\mathrm{eCO}_{2}$.

Conclusions The short-term fluctuation of $[\mathrm{N}]$ and $[\mathrm{K}]$ in nutrient solutions is caused by the asynchronous uptakes of $\mathrm{N}, \mathrm{K}$, and water under $\mathrm{eCO}_{2}$, which has an appreciable influence on $[\mathrm{N}]$ and $[\mathrm{K}]$ in plants besides the dilution effect. This defect of the closed hydroponic system may let us exaggerate the negative impact of $\mathrm{eCO}_{2}$ itself on $[\mathrm{N}]$ and $[\mathrm{K}]$ in plants.

Keywords Nitrogen concentration · Phosphorous concentration · Photosynthesis · Potassium concentration · Transpiration · Water consumption
Abbreviations
ANOVA Analysis of variance
$\mathrm{aCO}_{2}$ Ambient atmospheric $\mathrm{CO}_{2}$ concentration
DAT Days after transplanting
DW Dry weight
$\mathrm{eCO}_{2} \quad$ Elevated atmospheric $\mathrm{CO}_{2}$ concentration
LED Light-emitting diode 


$\begin{array}{ll}\text { LSD } & \text { Least-significant difference } \\ \text { OTC } & \text { Open-top chamber } \\ \text { Pn } & \text { Net photosynthetic rate } \\ \text { PVC } & \text { Polyvinyl chloride } \\ \text { R/S } & \text { Root to shoot dry weight ratio } \\ \text { SLW } & \text { Specific leaf weight } \\ \text { Tr } & \text { Transpiration rate }\end{array}$

\section{Introduction}

Due to the anthropogenic activities since the preindustrial era, atmospheric $\mathrm{CO}_{2}$ concentration $\left(\left[\mathrm{CO}_{2}\right]\right)$ has increased rapidly from $280 \mu \mathrm{mol} \cdot \mathrm{mol}^{-1}$ in 1750 to more than $400 \mu \mathrm{mol} \cdot \mathrm{mol}^{-1}$ recently (National Oceanic and Atmospheric Administration 2020). It will continue to rise and reach $800 \mu \mathrm{mol} \cdot \mathrm{mol}^{-1}$ by the end of this century if the emission of $\mathrm{CO}_{2}$ is not well controlled (Meinshausen et al. 2011). $\mathrm{CO}_{2}$ is a crucial component of plant photosynthesis, so elevated $\left[\mathrm{CO}_{2}\right]\left(\mathrm{eCO}_{2}\right)$ can not only promote the net photosynthesis rate but also depress the transpiration rate (Lawlor and Mitchell 1991; Rogers and Dahlman 1993). Consequently, the uptake, utilization, and allocation of the mineral elements by plants are dramatically influenced by $\mathrm{eCO}_{2}$, resulting in a significant change in mineral element concentrations in plants (Dong et al. 2018; Jin et al. 2019; Taub and Wang 2008).

Meta-analysis studies have reviewed that the concentrations of three major nutrient elements in plants, i.e., nitrogen $(\mathrm{N})$, phosphorus $(\mathrm{P})$, and potassium $(\mathrm{K})$, were all decreased by $7 \sim 15 \%, 1 \sim 7.5 \%$, and about $10 \%$, respectively (Cotrufo et al. 1998; Deng et al. 2015; Dong et al. 2018; Loladze 2002; Sardans et al. 2017). Some possible mechanisms for this phenomenon have been proposed. Firstly, the dilution effect by the accumulation of non-structural carbohydrates is the most frequently documented hypothesis for the reduction of mineral concentrations under $\mathrm{eCO}_{2}$ (Gifford et al. 2000; Taub and Wang 2008). Secondly, the stomatal conductance is significantly decreased when the plants are exposed to $\mathrm{eCO}_{2}$, followed by the decrease in both transpiration and mass flow, so the mineral elements absorbed by roots and transported to above-ground parts are limited (McDonald et al. 2002; McGrath and Lobell 2013). Thirdly, concerning N, decreased $\mathrm{N}$ demands due to improved $\mathrm{N}$ use efficiency and inhibited photorespiration-dependent $\mathrm{NO}_{3}{ }^{-}$assimilation are another two key factors affecting the $\mathrm{N}$ concentration ([N]) in plants under $\mathrm{eCO}_{2}$ (Bloom et al. 2010; Gifford et al. 2000; Stitt and Krapp 1999).

For dealing with plants' mineral nutrient status under $\mathrm{eCO}_{2}$, closed hydroponic experiments are usually conducted due to their accurate nutrient inputs and less interference from soil and microorganisms (Gruda 2019). In many studies, classical nutrient solution formulations are widely used, such as Hoagland and Arnon, Puppo and Rigaud, and Yamazaki nutrient solution. They were entirely renewed with an update period of 2 to 7 days in many experimental trials (Asensio et al. 2015; Bloom et al. 2010; Jauregui et al. 2017; Li et al. 2019; Ma et al. 2018; Niu et al. 2013; RodriguezHernandez Mdel et al. 2014; Vicente et al. 2017; Yilmaz et al. 2016). The concentrations and proportions of mineral elements in the classical nutrient solution formulations are usually optimized based on the water and mineral demands of plants grown in ambient $\left[\mathrm{CO}_{2}\right]$ $\left(\mathrm{aCO}_{2}\right)$ condition, so that they could maintain nearly invariant levels for several days (Hoagland and Arnon 1938; Yamazaki 1982). However, when plants are exposed to $\mathrm{eCO}_{2}$, their demands for water and each mineral nutrient are quite different from those under $\mathrm{aCO}_{2}$ due to the depressed transpiration (Houshmandfar et al. 2018; McGrath and Lobell 2013) and the change of metabolic process (Gifford et al. 2000; Rogers et al. 1993; Taub and Wang 2008; Yi et al. 2020). Conceivably, the concentration of each mineral element in the nutrient solution will not stay at the initial value until complete replacement, which may, in turn, have a significant impact on its concentration in plants under $\mathrm{eCO}_{2}$.

For example, it has been frequently reported that both the $\mathrm{N}$ demands and transpiration were decreased under $\mathrm{eCO}_{2}$ (Cotrufo et al. 1998; Deng et al. 2015; McGrath and Lobell 2013; Taub and Wang 2008). If water consumption is decreased more than $\mathrm{N}$ consumption, $[\mathrm{N}]$ in the nutrient solution will decline gradually. The longer the solution replacement interval lasts the lower the $\mathrm{N}$ remains, which could directly aggravate the $\mathrm{N}$ deficiency in plants under $\mathrm{eCO}_{2}$. On the contrary, the decline in plant $[\mathrm{N}]$ may be alleviated due to the accumulation of $\mathrm{N}$ in the nutrient solution as the experiment progressed. Moreover, in these studies mentioned above, plants were all grown in small containers with limited nutrient solutions $\left(0.25\right.$ to $\left.2.7 \mathrm{~L} \mathrm{plant}^{-1}\right)$, which may cause a considerable fluctuation of nutrient concentrations. It is in urgent need to check whether the mineral element 
concentrations will fluctuate under $\mathrm{eCO}_{2}$ due to the defect of the closed hydroponic experimental facilities. Moreover, it is interesting to know whether the shortterm fluctuation within the uptake duration of nutrient solutions could regulate the mineral concentrations in plants under $\mathrm{eCO}_{2}$. Both have received little attention in previous studies.

$\mathrm{N}$ is an essential nutrient that is often limiting plant growth in natural environments (Lambers et al. 2008). N deficiency could accelerate the photosynthetic acclimation, premature senescence, and quality deterioration in plants grown under $\mathrm{eCO}_{2}$ (Agüera and De la Haba 2018; Stitt and Krapp 1999). Therefore, increasing the N supply to keep step with carbon (C) inputs and coordinating the $\mathrm{C}$ to $\mathrm{N}$ ratio are recommended to alleviate or counteract the negative impact of $\mathrm{eCO}_{2}$ on plants (Halpern et al. 2019; Pettersson and McDonald 1994; Sanz-Saez et al. 2010). Thus, we hypothesized that N, P, K, and water consumptions would be dramatically changed in plants grown under $\mathrm{eCO}_{2}$ conditions compared with that under $\mathrm{aCO}_{2}$ conditions in different $\mathrm{N}$ supplies. Therefore, the consumption change would result in a significant fluctuation of mineral concentrations in the nutrient solution followed by the considerable impact on their concentrations in plants. In the present study, a hydroponic experiment on cucumber plants was conducted with two $\left[\mathrm{CO}_{2}\right]$ and three $\mathrm{N}$ levels. Four liters of the nutrient solution for one plant was entirely renewed every 4 to 7 days. The concentrations of N, P ([P]), and $\mathrm{K}([\mathrm{K}])$ in the residual nutrient solution and cucumber plants, net photosynthesis rate, and transpiration rate were measured. The objectives of this study were (1) to characterize the consumptions of $\mathrm{N}, \mathrm{P}, \mathrm{K}$, and water by cucumber plants under different $\left[\mathrm{CO}_{2}\right]$ and $\mathrm{N}$ supply conditions, and (2) to assess the contribution of the short-term fluctuation of $[\mathrm{N}],[\mathrm{P}]$, and $[\mathrm{K}]$ in the nutrient solution on their concentrations in cucumber plants.

\section{Materials and methods}

Plant culture

Pot experiments were conducted in the glasshouse at Institute of Soil Science, Chinese Academy of Sciences, Nanjing, P.R. China (32.0596 $\left.{ }^{\circ} \mathrm{N}, 118.8050^{\circ} \mathrm{E}\right)$. Cucumber (Cucumis sativus L.) seeds of cv. 'Jinyou 38' (Tianjin Lvfeng Co., Ltd., Tianjin, China) were surface sterilized with $10 \%$ sodium hypochlorite for $15 \mathrm{~min}$, washed with ultra-pure water thoroughly, and then germinated on moist filter paper in a growth chamber at $28{ }^{\circ} \mathrm{C}$ and relative humidity of $70 \%$. Three days later, the seeds with radicles were sown into trays containing peat-vermiculite mixture $(2: 1, \mathrm{v} / \mathrm{v})$ substrate. After 2 weeks, seedlings with three fully expanded true leaves were transplanted to polyvinyl chloride polymer (PVC) pots with $4 \mathrm{~L}$ of nutrient solution and two plants per pot, under $\mathrm{aCO}_{2}$ conditions. Eleven days after transplanting (DAT), seedlings with five fully expanded true leaves were transplanted to PVC pots containing $4 \mathrm{~L}$ nutrient solution with one plant per pot and transferred into two open-top chambers (OTCs) $(2.3 \mathrm{~m}$ length $\times 0.8 \mathrm{~m}$ width $\times 1.4 \mathrm{~m}$ height) with natural solar radiation. Individual cucumber plants were inserted into the hole on the cover of PVC pots, held with black foam sleeves, sealed with aluminum foil tape to minimize the solvent evaporation, and hung with wires to keep vertical growing.

The experiment was carried out as a split-plot design with $\left[\mathrm{CO}_{2}\right]$ as the primary treatment and $\mathrm{N}$ supply as the sub-plot treatment. Three $\mathrm{N}$ treatments were set at 7 (low N, N1), 14 (moderate N, N2), and 21 (high N, N3) $\mathrm{mM}$, which was repeated in four pots in each chamber. Twelve pots in each chamber were rotated within and among chambers every week to reduce the chamber and positional effects. The $\left[\mathrm{CO}_{2}\right]$ and $\mathrm{N}$ supply treatments were implemented from 12 until 44 DAT. During this period, the $\left[\mathrm{CO}_{2}\right]$ in OTCs was controlled at either $\mathrm{aCO}_{2}$ (hereafter, also referred to as the $\mathrm{C} 1$ or $400 \mu \mathrm{mol} \cdot \mathrm{mol}^{-1}$ treatment), or $\mathrm{eCO}_{2}$ (the $\mathrm{C} 2$ or $800 \mu \mathrm{mol} \cdot \mathrm{mol}^{-1}$ treatment). Carbon dioxide concentrations in the chambers were monitored every $5 \mathrm{~min}$ between 0900 and $1600 \mathrm{~h}$ each sunny and cloudy day using an infrared gas analyzer (Ultramat 6, Siemens, Munich, Germany). The accumulated $\mathrm{CO}_{2}$ treating time was $189 \mathrm{~h}$ in the whole experiment, and the average $\left[\mathrm{CO}_{2}\right]$ achieved were $397.1 \pm 5.9$ and $807.0 \pm$ $7.8 \mu \mathrm{mol} \cdot \mathrm{mol}^{-1}$ (means $\pm \mathrm{SD}$ ) for the $\mathrm{aCO}_{2}$ and $\mathrm{eCO}_{2}$ treatments, respectively (Fig. S1). According to the data recorded by a L95-83 data logger (Hangzhou loggertech Co., Ltd., Hangzhou, China) every $15 \mathrm{~min}$, the average temperature in OTCs was $23.7 \pm 3.3{ }^{\circ} \mathrm{C}(\mathrm{C} 1)$ and $24.1 \pm 3.0{ }^{\circ} \mathrm{C}(\mathrm{C} 2)$, and the average humidity was $56.3 \pm 9.7 \%(\mathrm{C} 1)$ and $58.6 \% \pm 10.2 \%$ (C2), respectively.

Yamazaki nutrient solution for cucumber (Yamazaki 1982) was used as the moderate $\mathrm{N}$ treatment (N2), and was modified to create the low $\mathrm{N}(\mathrm{N} 1)$ and high $\mathrm{N}(\mathrm{N} 3)$ treatments (Table 1). To ensure the same $\mathrm{NH}_{4}{ }^{+}: \mathrm{NO}_{3}{ }^{-}$ 
ratios, and $\mathrm{P}, \mathrm{K}$, and $\mathrm{Mg}$ concentrations in all three $\mathrm{N}$ treatments, anions and cations were balanced with $\mathrm{SO}_{4}{ }^{2}$ - and $\mathrm{Ca}^{2+}$, respectively. Micro-nutrients were included as follows: $\left(\mathrm{mg} \cdot \mathrm{L}^{-1}\right)$ : $\mathrm{Na}_{2} \mathrm{Fe}$-EDTA (29.27), $\mathrm{H}_{3} \mathrm{BO}_{3}$ (2.86), $\mathrm{MnSO}_{4} \cdot 4 \mathrm{H}_{2} \mathrm{O}(2.03), \mathrm{ZnSO}_{4} \cdot 7 \mathrm{H}_{2} \mathrm{O}(0.22)$, $\mathrm{CuSO}_{4} \cdot 5 \mathrm{H}_{2} \mathrm{O}(0.08)$, and $\left(\mathrm{NH}_{4}\right)_{6} \mathrm{Mo}_{7} \mathrm{O}_{24} \cdot 4 \mathrm{H}_{2} \mathrm{O}(0.02)$. The $\mathrm{pH}$ of the nutrient solutions was adjusted to $\mathrm{pH} 6.5$ by adding diluted $\mathrm{NaOH}$. A bacteriostat (Micropur, $1.0 \mathrm{mg} \cdot \mathrm{L}^{-1}$; Sicheres Trinkwasser, Germany) was added to inhibit the activity of microorganisms (Amann and Amberger 1989). The solutions were aerated for $30 \mathrm{~min}$ every hour and were completely replaced on 11, 16, 22, 26, 31, 37, and 44 DAT (Fig. S1). The old solutions were retained for subsequent analysis of nutrient depletion.

\section{Determination of leaf gas exchange parameters}

The gas exchange measurements of cucumber plants were evaluated on six fully expanded leaves from individual cucumber plants from 0900 to $1500 \mathrm{HR}$ on 44 DAT. The net photosynthetic rate (Pn) and transpiration rate $(\mathrm{Tr})$ of cucumber plants were measured by a portable photosynthesis system (Li-6400, Li-Cor Inc., Lincoln, OR, USA) with a standard leaf chamber $(2 \mathrm{~cm} \times$ $3 \mathrm{~cm})(6400-02 \mathrm{~B})$ and a LED light source. The $\left[\mathrm{CO}_{2}\right]$ of the flow-in air was set to the same level as the relevant treatment. The photosynthetic photon flux density, temperature, relative air humidity, and the air-flow rate inside the leaf chamber were set at $1500 \mu \mathrm{mol} \cdot \mathrm{m}^{-2} \cdot \mathrm{s}^{-1}$, $25^{\circ} \mathrm{C}, 50 \%$, and $500 \mu \mathrm{mol} \cdot \mathrm{s}^{-1}$, respectively.

The residual nutrient solution collection and analysis

The residual nutrient solution in the pots was collected before replacement on the same day when the fresh nutrient solution was added. They were suction-filtered through 0.45- $\mu \mathrm{m}$ Millipore membrane (Merck Millipore, Billerica, MA, USA) and weighed immediately after collection, and $200 \mathrm{~mL}$ of each filtrate was stored at $-18{ }^{\circ} \mathrm{C}$ for further determination. The $\mathrm{NO}_{3}{ }^{-}$ and $\mathrm{NH}_{4}{ }^{+}$concentrations in the residual nutrient solutions were determined with an automatic continuous segmented flow analyzer (SAN++, Skalar Analytical B.V., Breda, The Netherlands). The $\mathrm{PO}_{4}{ }^{3-}$ and $\mathrm{K}^{+}$concentrations in the residual nutrient solutions were quantified using an inductive coupled plasma optical emission spectrometry (Optima 8000, PerkinElmer, Waltham, MA, USA). [N] in the residual nutrient solution was calculated as the sum of $\mathrm{NO}_{3}{ }^{-}$and $\mathrm{NH}_{4}{ }^{+}$concentrations. $[\mathrm{P}]$ and $[\mathrm{K}]$ were represented by the $\mathrm{PO}_{4}{ }^{3-}$ and $\mathrm{K}^{+}$concentrations, respectively.

Plant harvest and analysis

Cucumber plants were harvested on 44 DAT immediately after the gas exchange measurements. The plants were separated to root, stem, leaf, and fruit samples and washed with tap water followed by distilled water. Dry weight (DW) of each organ was obtained by drying the fresh samples at $105{ }^{\circ} \mathrm{C}$ for $30 \mathrm{~min}$ and then at $75{ }^{\circ} \mathrm{C}$ to a constant weight in an electro-thermostatic oven. All the fresh leaves on the individual plants were stacked together, and the leaf numbers were recorded. Fresh leaf discs (12$\mathrm{mm}$ diameter) were cut by a hole-punch and placed into aluminum cups, then dried at $75^{\circ} \mathrm{C}$ to a constant weight. Specific leaf weight (SLW) was determined as the ratio of dry weight to the total area of leaf discs. Based on the SLW and DW of leaves, the total leaf area of individual plants was calculated. Dry samples were ground to pass through a 0.5 - $\mathrm{mm}$ sieve, and $200 \mathrm{mg}$ of each sample was soaked in $5 \mathrm{~mL}$ concentrated $\mathrm{H}_{2} \mathrm{SO}_{4}$ for $24 \mathrm{~h}$ then digested at $180^{\circ} \mathrm{C}$ for $5 \mathrm{~h}$, followed by intermittent addition of $0.5 \mathrm{~mL} \mathrm{H}_{2} \mathrm{O}_{2}$ for 2 to 3 times. The extracted solution was diluted with deionized water, and $[\mathrm{N}]$ was determined using a colorimetric method based on the salicylate-chlorine reaction and absorption spectrometry with sodium nitroprusside and sodium dichloroisocyanurate by an automated Discrete Chemistry Analyzer (Smartchem 200, Westco Scientific Instruments Inc., Rome, Italy) (Reardon et al. 1966). Another portion of 200-mg dry samples was digested with $5 \mathrm{~mL} \mathrm{HNO}_{3}-\mathrm{HClO}_{4}(85: 15 \mathrm{v} / \mathrm{v})$ at $190{ }^{\circ} \mathrm{C}$, and $[\mathrm{P}]$ and $[\mathrm{K}]$ were analyzed by an inductively coupled plasma atomic optical emission spectrometer (ICP-OES) (Optima 8000, PerkinElmer, Boston, USA) (Zhao et al. 2008).

\section{Statistical analysis}

Statistical analysis and figures were generated by OriginPro (Version 2019b; OriginLab Corp., Northampton, MA, USA). All data were shown as mean \pm standard error. The means of DW, gas exchange properties, mineral concentrations, consumptions, and accumulations with four replicates in each treatment were compared using Fisher LSD test at a significance level of $p=0.05$ by using the application "Paired Comparison Plot" in OriginPro. The effects of $\mathrm{N}$ supply level and $\left[\mathrm{CO}_{2}\right]$, and their interaction on DW, gas exchange 
Table 1 Components of macro-nutrient elements in solutions with different $\mathrm{N}$ levels. -, no chemicals

\begin{tabular}{|c|c|c|c|c|c|c|c|c|c|c|c|c|c|c|}
\hline \multirow[t]{3}{*}{$\mathrm{N}$ levels } & \multicolumn{6}{|c|}{ Compounds (mmol L ${ }^{-1}$ ) } & \multicolumn{8}{|c|}{ Elements (mmol L $\left.{ }^{-1}\right)$} \\
\hline & \multirow[t]{2}{*}{$\mathrm{Ca}\left(\mathrm{NO}_{3}\right)_{2} \cdot 4 \mathrm{H}_{2} \mathrm{O}$} & \multirow[t]{2}{*}{$\mathrm{KNO}_{3}$} & \multirow[t]{2}{*}{$\mathrm{NH}_{4} \mathrm{NO}_{3}$} & \multirow[t]{2}{*}{$\mathrm{MgSO}_{4} \cdot 7 \mathrm{H}_{2} \mathrm{O}$} & \multirow[t]{2}{*}{$\mathrm{K}_{2} \mathrm{SO}_{4}$} & \multirow[t]{2}{*}{$\mathrm{Ca}\left(\mathrm{H}_{2} \mathrm{PO}_{4}\right)_{2} \cdot \mathrm{H}_{2} \mathrm{O}$} & \multicolumn{3}{|l|}{$\mathrm{N}$} & \multirow[t]{2}{*}{$\mathrm{P}$} & \multirow[t]{2}{*}{$\mathrm{K}$} & \multirow[t]{2}{*}{$\mathrm{Ca}$} & \multirow[t]{2}{*}{$\mathrm{Mg}$} & \multirow[t]{2}{*}{$\mathrm{S}$} \\
\hline & & & & & & & Total & $\mathrm{NH}_{4}^{+}$ & $\mathrm{NO}_{3}^{-}$ & & & & & \\
\hline N1 & 3 & - & 0.5 & 2 & 3 & 0.5 & 7 & 0.5 & 6.5 & 1 & 6 & 3.5 & 2 & 5 \\
\hline $\mathrm{N} 2$ & 3 & 6 & 1 & 2 & - & 0.5 & 14 & 1 & 13 & 1 & 6 & 3.5 & 2 & 2 \\
\hline N3 & 6 & 6 & 1.5 & 2 & - & 0.5 & 21 & 1.5 & 19.5 & 1 & 6 & 6.5 & 2 & 2 \\
\hline
\end{tabular}

properties, mineral concentrations, consumptions, and accumulations were quantified using two-way analysis of variance (ANOVA) at a significance level of $p=$ 0.05 . Linear regression analyses and significance tests were performed using the application "Simple Fit" (a linear model function) in OriginPro. The 95\% confidence interval for the regression slope was also constructed in the figures.

\section{Results}

The growth and gas exchange properties of cucumber plants

The growth parameters of cucumber plants in response to $\left[\mathrm{CO}_{2}\right]$ and $\mathrm{N}$ supply levels are shown in Fig. 1. Twoway ANOVA results showed a significant effect of $\left[\mathrm{CO}_{2}\right]$ and $\mathrm{N}$ supply levels on the DW formation of cucumber plants. The root, stem, leaf, fruit, and total DW were significantly higher under $\mathrm{eCO}_{2}$ than those under $\mathrm{aCO}_{2}$ condition in high $\mathrm{N}$ supply (N3), whereas the increase of aerial part DW in low N supply (N1) was not significant. Averagely, the increase of total DW was $39.6 \%$ (not significant $=$ n.s.), $76.2 \%$, and $84.3 \%$ by $\mathrm{eCO}_{2}$ in $\mathrm{N} 1, \mathrm{~N} 2$, and N3 supply, respectively. Meanwhile, the increase of DW in different organs by higher $\mathrm{N}$ supply was dramatic under $\mathrm{eCO}_{2}$ but not noticeable under $\mathrm{aCO}_{2}$. Compared with the low $\mathrm{N}$ treatment, the total DW was $71.6 \%$ and $126.6 \%$ higher in the high $\mathrm{N}$ treatment under $\mathrm{aCO}_{2}$ and $\mathrm{eCO}_{2}$, respectively. Increasing the $\mathrm{N}$ supply resulted in a significant decrease of root/shoot DW ratio $(\mathrm{R} / \mathrm{S})$, whereas the $\mathrm{R} / \mathrm{S}$ was less affected by $\mathrm{eCO}_{2}$ regardless of $\mathrm{N}$ supply. SLW was $23.9 \%$ higher under $\mathrm{eCO}_{2}$ than that under $\mathrm{aCO}_{2}$ only in high $\mathrm{N}$ supply and was $17.5 \%$ higher in high $\mathrm{N}$ supply than that in low $\mathrm{N}$ supply only under $\mathrm{eCO}_{2}$ condition.
Like the leaf DW, a significant increase of the leaf area per plant was observed by $\mathrm{eCO}_{2}$ in moderate (N2) and high (N3) N supply, and the increase was $117.3 \%$ and $64.4 \%$, respectively. Moreover, the increase of the leaf area per plant by increasing $\mathrm{N}$ supply was significant only under $\mathrm{eCO}_{2}$ condition and was $57.2 \%$ and $70.7 \%$ in $\mathrm{N} 2$ and $\mathrm{N} 3$ treatment compared with $\mathrm{N} 1$ treatment, respectively.

As shown in Fig. 2, the gas exchange rates measurements indicated that the Pn of cucumber plants grown under $\mathrm{eCO}_{2}$ was 1.91- to 2.12-fold higher than that under $\mathrm{aCO}_{2}$ condition. Due to the larger leaf area per plant under $\mathrm{eCO}_{2}$ condition, the $\mathrm{Pn}$ per plant was much larger under $\mathrm{eCO}_{2}$ than that under $\mathrm{aCO}_{2}$. The Pn per plant under $\mathrm{eCO}_{2}$ was 2.61, 4.97, and 3.25 times as much as those under $\mathrm{aCO}_{2}$ condition in $\mathrm{N} 1, \mathrm{~N} 2$, and $\mathrm{N} 3$ treatment, respectively. Under $\mathrm{eCO}_{2}$, the Pn per plant was increased by $87.2 \%$ and $95.2 \%$ in the moderate and high $\mathrm{N}$ treatment compared with that in the low $\mathrm{N}$ treatment, respectively. The $\mathrm{Tr}$ of cucumber plants was significantly inhibited by $\mathrm{eCO}_{2}$ in low and moderate $\mathrm{N}$ supplies but only had a declining trend in high $\mathrm{N}$ supply. Generally, the $\operatorname{Tr}$ under $\mathrm{eCO}_{2}$ was $48.1 \%$, $35.2 \%$, and $29.9 \%$ (n.s.) lower than those under $\mathrm{aCO}_{2}$ condition, in N1, N2, and N3 treatment, respectively. Concerning $\mathrm{Tr}$ per plant, larger leaf area per plant counteracted the decrease of $\mathrm{Tr}$ under $\mathrm{eCO}_{2}$ condition. Therefore, $\mathrm{Tr}$ per plant under $\mathrm{eCO}_{2}$ has little difference with or even larger than that under $\mathrm{aCO}_{2}$ due to the larger leaf area per plant. The increase of $\operatorname{Tr}$ per plant by $\mathrm{eCO}_{2}$ was $59.4 \%$ and $39.7 \%$ (n.s.) in the moderate and high $\mathrm{N}$ treatment, respectively.

The fluctuation of $[\mathrm{N}],[\mathrm{P}]$, and $[\mathrm{K}]$ in nutrient solutions

Figure 3 shows the fluctuation of $[\mathrm{N}]$ in six rounds of nutrient solution treatments with three $\mathrm{N}$ supply levels, 


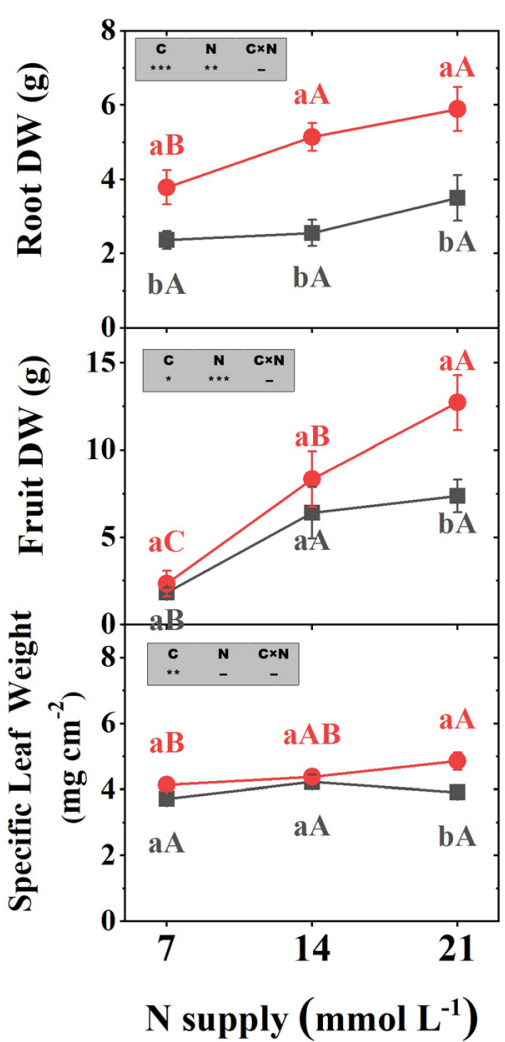

Fig. 1 Dry weights (DW) of roots, stems, leaves, fruits, whole plants, root/shoot ratios, specific leaf dry weights, and leaf areas of cucumber plants grown under different $\mathrm{CO}_{2}$ and $\mathrm{N}$ levels $(n=4)$. Bars represent standard errors. Means not followed by the same lower case letters are significantly different among different $\mathrm{CO}_{2}$ levels in the same $\mathrm{N}$ level, and not followed by the same upper

from which a general dilution of $[\mathrm{N}]$ during the plant growth was found. $[\mathrm{N}]$ in the residual nutrient solution under $\mathrm{eCO}_{2}$ was lower than that under $\mathrm{aCO}_{2}$ condition. The decrease was significant in the first (from 11 DAT to $16 \mathrm{DAT}$ ), the fourth (from $26 \mathrm{DAT}$ to $31 \mathrm{DAT}$ ), and the fifth (from $31 \mathrm{DAT}$ to $37 \mathrm{DAT}$ ) round of nutrient solution treatments in all three $\mathrm{N}$ levels. It is noteworthy that $[\mathrm{N}]$ in the residual nutrient solution of $\mathrm{N} 1$ treatments were less than $4 \mathrm{mM}$ or even $2 \mathrm{mM}$ in the first three rounds. Although the decrease by $\mathrm{eCO}_{2}$ was significant in all the six rounds in $\mathrm{N} 3$ treatments, $[\mathrm{N}]$ in the six residual nutrient solutions were still more than $7 \mathrm{mM}$.

$[\mathrm{P}]$ in the residual nutrient solution was also lower than its initial concentration in the fresh nutrient solution (Fig. 4). The effects of $\left[\mathrm{CO}_{2}\right]$ on $[\mathrm{P}]$ in the residual nutrient solution depended on the $\mathrm{N}$ supply levels and growth stages. In the first four rounds of nutrient solution treatments (from 11 DAT to $31 \mathrm{DAT}$ ), [P] in the residual

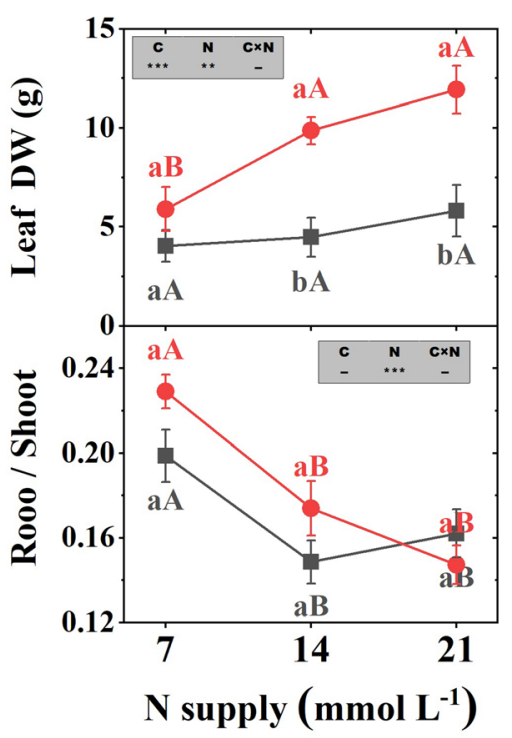

+ C1: $400 \mu \mathrm{mol} \mathrm{mol}^{-1}$ - C2: 800 $\mu \mathrm{mol} \mathrm{mol}^{-1}$ nutrient solution was significantly lower under $\mathrm{eCO}_{2}$ than that under $\mathrm{aCO}_{2}$ condition in all three $\mathrm{N}$ supply levels. The average decrease was $19.3 \%, 19.3 \%$, and $17.8 \%$ for $\mathrm{N} 1$, $\mathrm{N} 2$, and N3, respectively. In the last two rounds of nutrient solution treatments (from 31 DAT to 44 DAT), compared with that under $\mathrm{aCO}_{2}$ condition, $[\mathrm{P}]$ in the residual nutrient solution under $\mathrm{eCO}_{2}$ condition was decreased by $22.5 \%$ and $22.3 \%$ in $\mathrm{N} 1$ and $\mathrm{N} 2$ respectively, but stayed the same in N3. The N supply levels also had a significant impact on $[\mathrm{P}]$ in the residual nutrient solution. $[\mathrm{P}]$ in the residual nutrient solution showed a steep decrease with the $\mathrm{N}$ supply increasing in the whole experimental period under both $\left[\mathrm{CO}_{2}\right]$ conditions. Compared with that in $\mathrm{N} 1$, the average decrease in $\mathrm{N} 3$ was $21.2 \%$ and $16.6 \%$ under $\mathrm{aCO}_{2}$ and $\mathrm{eCO}_{2}$ condition, respectively. Although it was always the lowest in $\mathrm{N} 3$ under $\mathrm{eCO}_{2}$ condition, $[\mathrm{P}]$ in the residual nutrient solution ranged from 0.45 to $0.64 \mathrm{mM}$, about half of the initial value. 


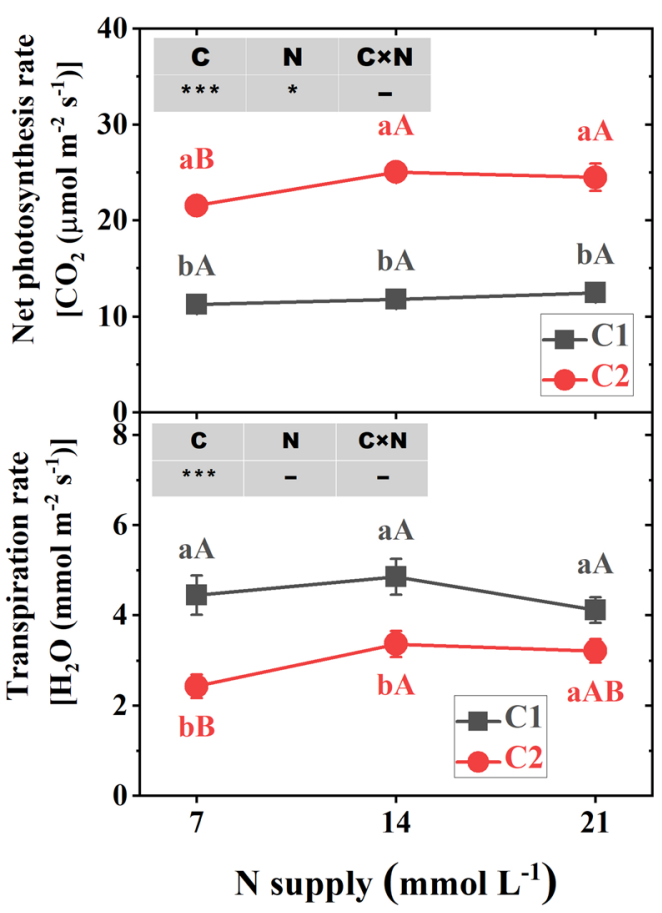

Fig. 2 Net photosynthesis rate, photosynthesis rate per plant, transpiration rate, and transpiration rate per plant of cucumber plants grown under different $\mathrm{CO}_{2}$ and $\mathrm{N}$ levels $(n=4)$. Bars represent standard errors. $\mathrm{CO}_{2}$ levels: $\mathrm{C} 1,400 \mu \mathrm{mol} \cdot \mathrm{mol}^{-1}$; $\mathrm{C} 2$, $800 \mu \mathrm{mol} \cdot \mathrm{mol}^{-1}$. Means not followed by the same lower case letters are significantly different among different $\mathrm{CO}_{2}$ levels in

$[\mathrm{K}]$ in the residual nutrient solution after six rounds of nutrient solution treatments is shown in Fig. 4. The final $[\mathrm{K}]$ was similar to its initial concentration in low $\mathrm{N}$ supply under $\mathrm{aCO}_{2}$ condition but was observably lower in high $\mathrm{N}$ supply under $\mathrm{eCO}_{2}$ condition. In $\mathrm{N} 1$ supply, no significant reduction in $[\mathrm{K}]$ in the residual nutrient solution was found under $\mathrm{eCO}_{2}$ compared with that under $\mathrm{aCO}_{2}$ condition, except for the fourth and fifth rounds (from 26 DAT to $37 \mathrm{DAT}$ ). In N2 and N3 supplies, $[\mathrm{K}]$ in the residual nutrient solution was significantly lower under $\mathrm{eCO}_{2}$ than that under $\mathrm{aCO}_{2}$ condition, except for the second round in $\mathrm{N} 2$ supply. The average decrease under $\mathrm{eCO}_{2}$ was $21.8 \%$ and $23.6 \%$ in $\mathrm{N} 2$ and $\mathrm{N} 3$, respectively. $[\mathrm{K}]$ in the residual nutrient solution also exhibited a general decline with the $\mathrm{N}$ supply increasing regardless of $\left[\mathrm{CO}_{2}\right]$ and growth stage. The decreases from N1 to N3 were $13.7 \%$ and $27.5 \%$ under $\mathrm{aCO}_{2}$ and $\mathrm{eCO}_{2}$ condition, respectively. The lowest value of $[\mathrm{K}]$ in the residual nutrient solution in the last four rounds ranged from 3.1 to $3.8 \mathrm{mM}$.

According to the water volume, $[\mathrm{N}],[\mathrm{P}]$, and $[\mathrm{K}]$ in the fresh and residual nutrient solution, the water, $\mathrm{N}, \mathrm{P}$,

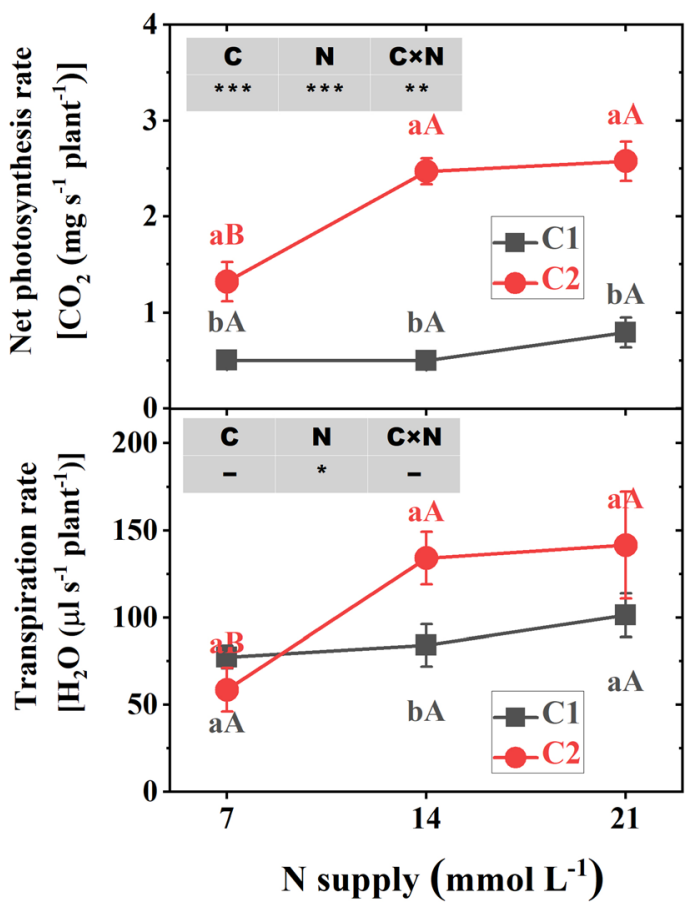

the same $\mathrm{N}$ level, and not followed by the same upper case letters are significantly different among different $\mathrm{N}$ levels in the same $\mathrm{CO}_{2}$ level, according to Fisher LSD test at $p<0.05$. In the internal table, $\mathrm{C}, \mathrm{CO}_{2}$ level; N, N level. Asterisks (*) indicate significant differences $(* p<0.05 ; * * p<0.01 ; * * * p<0.001)$; Hyphen (-) indicates non-significant differences $(p \geq 0.05)$

and $\mathrm{K}$ consumptions in each round and their total consumptions by individual cucumber plants from the nutrient solution were calculated (Fig. 5). When the plants received moderate $(\mathrm{N} 2)$ and high $(\mathrm{N} 3) \mathrm{N}$ supply, $\mathrm{eCO}_{2}$ significantly increased the water consumption per plant by $30.1 \%$ and $27.6 \%$ compared with those under $\mathrm{aCO}_{2}$ condition. The water consumption was dramatically increased by $75.9 \%$ with the $\mathrm{N}$ supply increasing from $\mathrm{N} 1$ to $\mathrm{N} 3$ under $\mathrm{eCO}_{2}$ condition. Elevated $\mathrm{N}$ supply significantly increased the $\mathrm{N}$ consumption per plant, and the average increases were $106.9 \%$ and $188.1 \%$ in $\mathrm{N} 3$ compared with that in $\mathrm{N} 1$ under $\mathrm{aCO}_{2}$ and $\mathrm{eCO}_{2}$ condition, respectively. In $\mathrm{N} 2$ and $\mathrm{N} 3$ treatments, $\mathrm{eCO}_{2}$ increased the $\mathrm{N}$ consumption per plant by $60.9 \%$ and $72.9 \%$, respectively. The P consumption per plant was steadily increased with either $\mathrm{N}$ supply or $\left[\mathrm{CO}_{2}\right]$ increasing. The increase of $\mathrm{P}$ consumption per plant by $\mathrm{eCO}_{2}$ was $60.4 \%, 50.2 \%$, and $27.2 \%$ for $\mathrm{N} 1, \mathrm{~N} 2$, and $\mathrm{N} 3$, respectively. Compared with that in $\mathrm{N} 1$, the $\mathrm{P}$ consumption per plant was $73.7 \%$ and $37.8 \%$ higher in $\mathrm{N} 3$ under $\mathrm{aCO}_{2}$ and $\mathrm{eCO}_{2}$ condition, respectively. The $\mathrm{K}$ consumption per plant was significantly increased by 


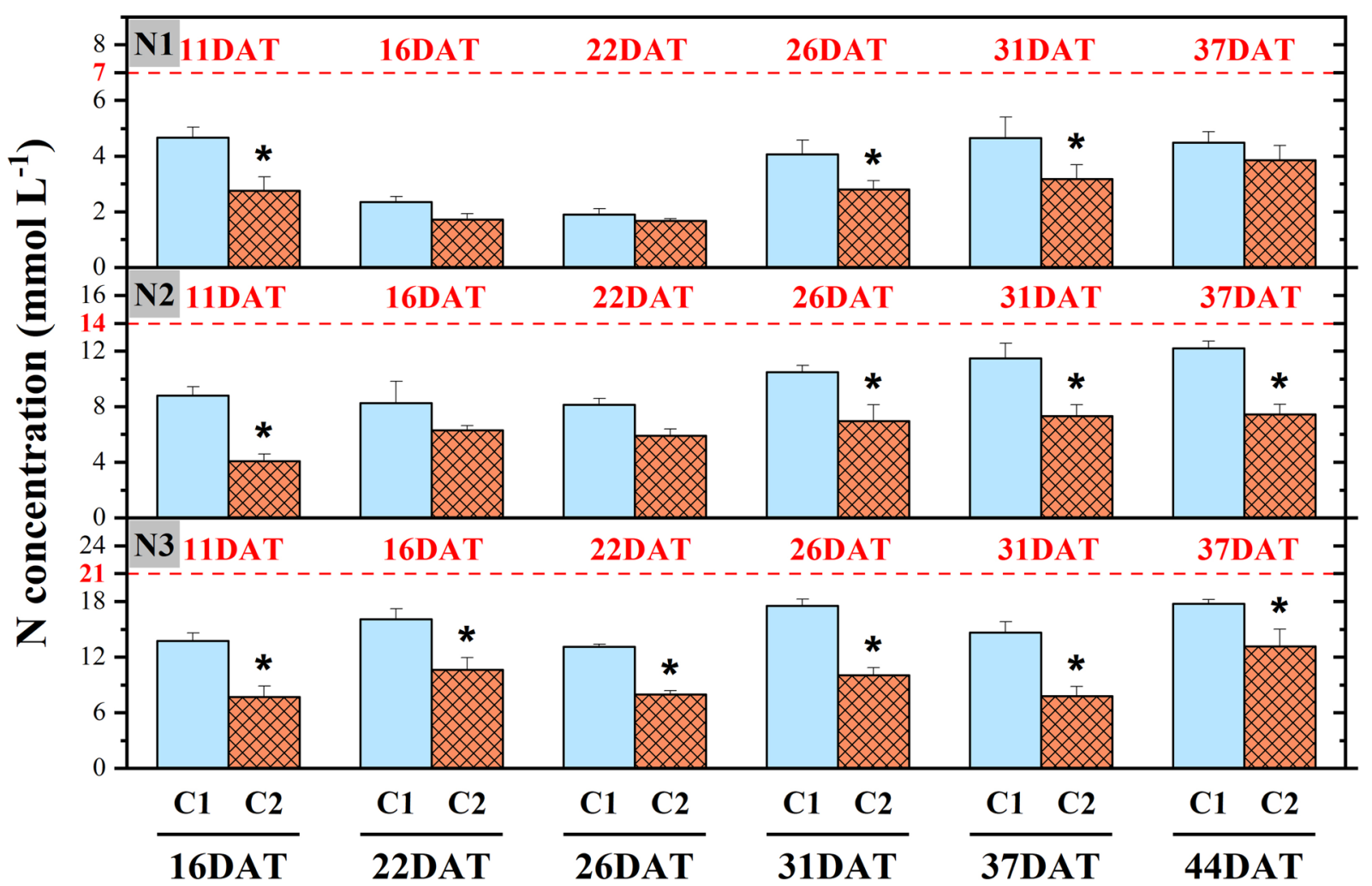

Fig. 3 The final nitrogen concentration in the residual nutrient solution on the day when the nutrient solution was renewed under different $\mathrm{CO}_{2}$ and $\mathrm{N}$ levels $(n=4)$. Bars represent standard errors. $\mathrm{CO}_{2}$ levels: $\mathrm{C} 1,400 \mu \mathrm{mol} \cdot \mathrm{mol}^{-1} ; \mathrm{C} 2,800 \mu \mathrm{mol} \cdot \mathrm{mol}^{-1}$. N levels: $\mathrm{N} 1,7 \mathrm{mmol} \mathrm{L}{ }^{-1}$; $2,14 \mathrm{mmol} \mathrm{L}^{-1}$; N3, $21 \mathrm{mmol} \mathrm{L}^{-1}$. Asterisk

$\left({ }^{*} p<0.05\right)$ indicates significant differences between two different $\mathrm{CO}_{2}$ levels in the same $\mathrm{N}$ level on the same day. The red dotted line and date indicate the initial nitrogen concentration in the fresh nutrient solution and the date on which the nutrient solution was renewed

$97.0 \%$ and $65.1 \%$ in $\mathrm{N} 2$ and $\mathrm{N} 3$ by $\mathrm{eCO}_{2}$, respectively. The increases of the $\mathrm{K}$ consumption per plant from $\mathrm{N} 1$ to $\mathrm{N} 3$ were $99.1 \%$ and $122.7 \%$ under $\mathrm{aCO}_{2}$ and $\mathrm{eCO}_{2}$ condition, respectively.

$[\mathrm{N}],[\mathrm{P}]$, and $[\mathrm{K}]$ and their accumulations in cucumber plants

$[\mathrm{N}],[\mathrm{P}]$, and $[\mathrm{K}]$ in different organs of cucumber plants gave us information about mineral nutrients status in different $\mathrm{N}$ supplies and $\left[\mathrm{CO}_{2}\right]$ treatments (Fig. 6). There was no significant decline of $[\mathrm{N}]$ in all organs of cucumber associated with $\mathrm{eCO}_{2}$ when plants received $\mathrm{N} 2$ or $\mathrm{N} 3$ supply, and the decrease was significant only in leaves $(-15.2 \%)$ and fruits $(-12.0 \%)$ when plants were grown in $\mathrm{N} 1$ supply. [N] in all cucumber plants' organs were increased from $\mathrm{N} 1$ to $\mathrm{N} 3$ in both $\left[\mathrm{CO}_{2}\right]$ treatments. There was no significant decrease in $[\mathrm{P}]$ in all organs of cucumber plants by $\mathrm{eCO}_{2}$ except for the roots received $\mathrm{N} 2$ or $\mathrm{N} 3$ supply. Elevated $\mathrm{CO}_{2}$ increased

[P] by $32.4 \%$ in stems and $29.0 \%$ in fruits received low $\mathrm{N}$ supply. Increasing the $\mathrm{N}$ supply from $\mathrm{N} 1$ to $\mathrm{N} 3$ has little effects on $[\mathrm{P}]$ in cucumber plants under $\mathrm{aCO}_{2}$ but decreased $[\mathrm{P}]$ by $32.5 \%, 28.6 \%$, and $27.7 \%$ in the roots, stems, and fruits under $\mathrm{eCO}_{2}$ condition, respectively. There were no significant differences in $[\mathrm{K}]$ in all organs of cucumber plants received low $\mathrm{N}$ supply between two $\left[\mathrm{CO}_{2}\right]$ treatments, whereas $\mathrm{eCO}_{2}$ dramatically reduced [K] by $20.2 \%$ in roots, $14.8 \%$ in stems, $24.3 \%$ in leaves, and $17.2 \%$ in fruits in cucumber plants received N3 supply. $\mathrm{N}$ supply also substantially impacted $[\mathrm{K}]$ in cucumber plants depending on the $\left[\mathrm{CO}_{2}\right]$ conditions. Under $\mathrm{aCO}_{2}$ condition, $[\mathrm{K}]$ was decreased by $24.6 \%$ in roots and increased by $85.5 \%$ in leaves when the $\mathrm{N}$ supply was increased from N1 to N3. However, under $\mathrm{eCO}_{2}$ condition, the decrease of $[\mathrm{K}]$ from $\mathrm{N} 1$ to $\mathrm{N} 3$ was $36.0 \%$ in roots and $19.0 \%$ in fruits.

Based on the DW and nutrient concentrations, the $\mathrm{N}$, $\mathrm{P}$, and $\mathrm{K}$ accumulations in different organs and the whole plant of cucumber grown under different $\left[\mathrm{CO}_{2}\right]$ 


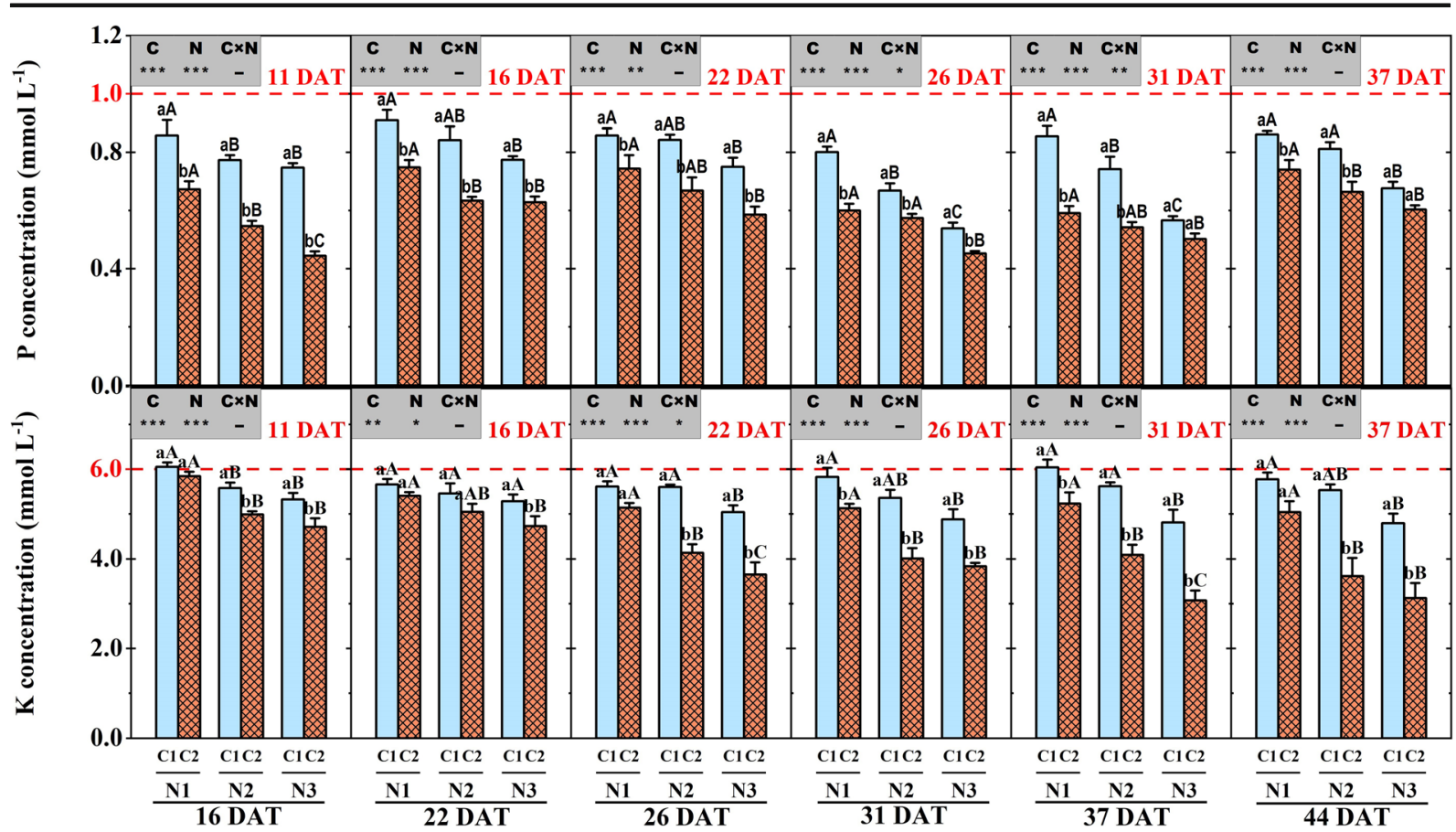

Fig. 4 The final phosphorus and potassium concentrations in the residual nutrient solution on the day when the nutrient solution was renewed under different $\mathrm{CO}_{2}$ and $\mathrm{N}$ levels $(n=4)$. Bars represent standard errors. $\mathrm{CO}_{2}$ levels: $\mathrm{C} 1,400 \mu \mathrm{mol} \cdot \mathrm{mol}^{-1}$; $\mathrm{C} 2$, $800 \mu \mathrm{mol} \cdot \mathrm{mol}^{-1}$. N levels: $\mathrm{N} 1,7 \mathrm{mmol} \mathrm{L}^{-1}$; N2, $14 \mathrm{mmol} \mathrm{L}^{-1}$; N3, $21 \mathrm{mmol} \mathrm{L}^{-1}$. Means not followed by the same lower case letters are significantly different among different $\mathrm{CO}_{2}$ levels in the same $\mathrm{N}$ level, and not followed by the same upper case letters are

and $\mathrm{N}$ levels were obtained (Fig. S2). Only P accumulation was increased by $\mathrm{eCO}_{2}$ in low $\mathrm{N}$ treatment, whereas the increases by $\mathrm{eCO}_{2}$ in high $\mathrm{N}$ treatment were $79.8 \%, 78.7 \%$, and $74.1 \%$ for $\mathrm{N}, \mathrm{P}$, and $\mathrm{K}$ accumulations, respectively. When the $\mathrm{N}$ supply was increased from $\mathrm{N} 1$ to $\mathrm{N} 3$, the $\mathrm{N}, \mathrm{P}$, and $\mathrm{K}$ accumulations were increased by $100.0 \%, 60.8 \%$, and $64.1 \%$ under $\mathrm{aCO}_{2}$ condition, and $192.2 \%, 72.2 \%$, and $115.7 \%$ under $\mathrm{eCO}_{2}$ condition, respectively. Significant positive correlations between mineral element accumulations per plant and the corresponding consumption from the nutrient solution in the whole experimental period were also observed, with the $\mathrm{R}^{2}$ of $0.919,0.867$, and 0.937 for $\mathrm{N}$, $\mathrm{P}$, and $\mathrm{K}$ element respectively (Fig. S3).

The correlations between biomass accumulation, gas exchange properties, and water and mineral element consumptions

To further evaluate the relationship between the biomass accumulation, water consumption, and gas exchange significantly different among different $\mathrm{N}$ levels in the same $\mathrm{CO}_{2}$ level, according to Fisher LSD test at $p<0.05$. In the internal table, $\mathrm{C}, \mathrm{CO}_{2}$ level; $\mathrm{N}, \mathrm{N}$ level. Asterisks (*) indicate significant differences $(* p<0.05 ; * * p<0.01 ; * * * p<0.001)$; Hyphen (-) indicates non-significant differences $(p \geq 0.05)$. The red dotted line and date indicate the initial phosphorus and potassium concentrations in the fresh nutrient solution and the date on which the nutrient solution was renewed

properties in different $\left[\mathrm{CO}_{2}\right]$ and $\mathrm{N}$ supply treatments, Pearson correlation coefficient was analyzed (Fig. 7). In the whole experimental period, there was a significant positive correlation between the total DW accumulation and the net photosynthesis rate per plant with the $\mathrm{R}^{2}$ of 0.700 . The water consumption was also positively correlated to the transpiration rate per plant $\left(\mathrm{R}^{2}=0.815\right)$. The correlations between $\mathrm{N}, \mathrm{P}$, and $\mathrm{K}$ consumptions and the water consumption per plant in cucumber plants were also generated by using the four replications data in six rounds of nutrient solution treatments (Fig. 7). All the $\mathrm{N}, \mathrm{P}$, and $\mathrm{K}$ consumptions from the nutrient solution were significantly positively correlated to the corresponding water consumption with the $\mathrm{R}^{2}$ of 0.194 , 0.484 , and 0.452 for $\mathrm{N}, \mathrm{P}$, and $\mathrm{K}$ element respectively (Fig. 7). When cucumber plants absorbed a certain mass (or volume) of water, the simultaneous absorption of $\mathrm{N}$ was significantly increased by $\mathrm{eCO}_{2}$ and higher $\mathrm{N}$ supply. The $\mathrm{P}$ consumption per unit water consumption was greater under $\mathrm{eCO}_{2}$ than that under $\mathrm{aCO}_{2}$ condition in low $\mathrm{N}$ and moderate $\mathrm{N}$ supply but not in high $\mathrm{N}$ supply. 


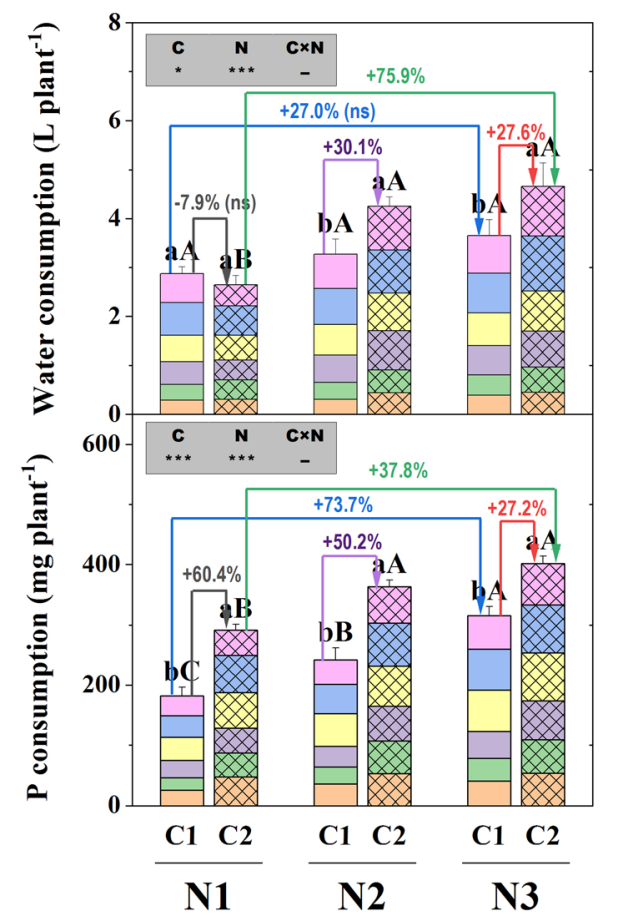

Fig. 5 The water, nitrogen, phosphorus, and potassium consumptions per plant in each nutrient solution round and the whole experimental period under different $\mathrm{CO}_{2}$ and $\mathrm{N}$ levels $(n=4)$. Bars represent standard errors. $\mathrm{CO}_{2}$ levels: $\mathrm{C} 1,400 \mu \mathrm{mol} \cdot \mathrm{mol}^{-1}$; $\mathrm{C} 2$, $800 \mu \mathrm{mol} \cdot \mathrm{mol}^{-1}$. N levels: $\mathrm{N} 1,7 \mathrm{mmol} \mathrm{L}^{-1} ; \mathrm{N} 2,14 \mathrm{mmol} \mathrm{L}^{-1}$; N3, $21 \mathrm{mmol} \mathrm{L}^{-1}$. Means not followed by the same lower case letters are significantly different among different $\mathrm{CO}_{2}$ levels in the same

Similarly, the K consumption per unit water consumption was more massive under $\mathrm{eCO}_{2}$ than that under $\mathrm{aCO}_{2}$ condition in $\mathrm{N} 1$ supply and increased with $\mathrm{N}$ supply increasing under $\mathrm{aCO}_{2}$ condition. The $\mathrm{N}, \mathrm{P}$, and $\mathrm{K}$ consumptions from the nutrient solution also had a strong positive correlation with the Tr per plant, and the $\mathrm{R}^{2}$ was highest for $\mathrm{N}(0.741)$ and lowest for $\mathrm{P}$ (0.549) (Fig. S4).

\section{Discussion}

Plant growth and gas exchange properties

The increases of the organs and total DW of cucumber plants in high $\mathrm{N}$ supply and $\mathrm{eCO}_{2}$ treatments in this work are consistent with previous reports (Dong et al. 2017; Kläring et al. 2007; Li et al. 2018; Li et al. 2020; Peet 1986). Our results demonstrated that the biomass accumulation was positively correlated to the net photosynthesis rate per plant (Fig. 7), which indicated that

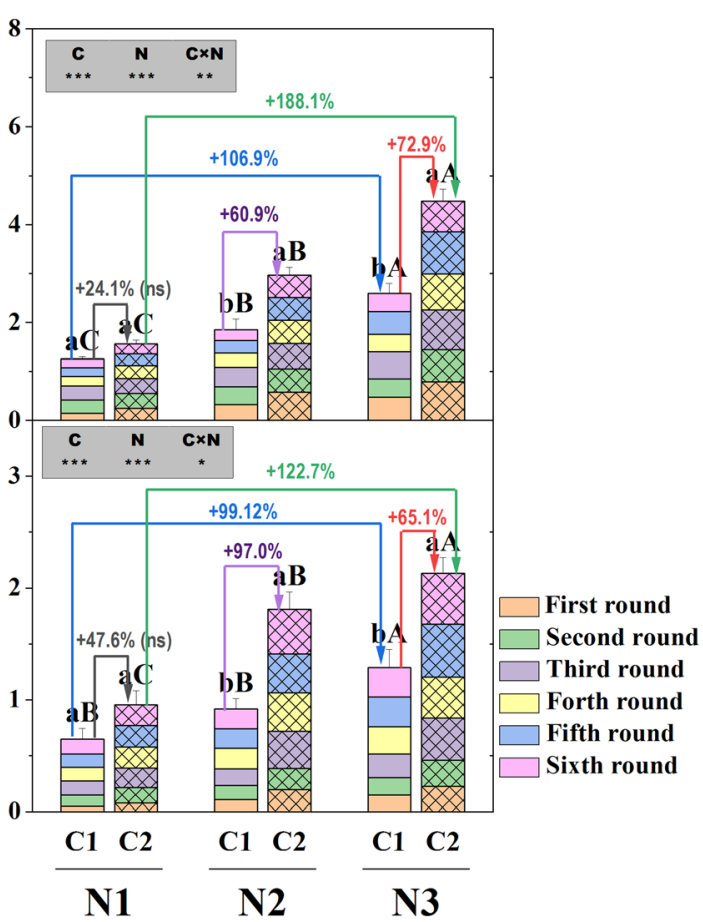

$\mathrm{N}$ level, and not followed by the same upper case letters are significantly different among different $\mathrm{N}$ levels in the same $\mathrm{CO}_{2}$ level, according to Fisher LSD test at $p<0.05$. In the internal table, $\mathrm{C}, \mathrm{CO}_{2}$ level; $\mathrm{N}, \mathrm{N}$ level. Asterisks (*) indicate significant differences $(* p<0.05 ; * * p<0.01 ; * * * p<0.001)$; Hyphen $(-)$ indicates non-significant differences $(p \geq 0.05)$

$\mathrm{eCO}_{2}$ promoted the fixation of $\mathrm{CO}_{2}$ and thus biomass accumulation under moderate or high $\mathrm{N}$ supply (Reich et al. 2006; van der Kooi et al. 2016). It has been reported that $\mathrm{eCO}_{2}$ usually increases $\mathrm{R} / \mathrm{S}$ in nutrientlimiting condition because the increased biomass by $\mathrm{eCO}_{2}$ will be preferentially allocated to roots to exploit and acquire more nutrients (Rogers et al. 1994; Stulen and Denhertog 1993). In the present study, there was only an increasing trend in $\mathrm{R} / \mathrm{S}$ by $\mathrm{eCO}_{2}$ in $\mathrm{N} 1$ and $\mathrm{N} 2$ treatments (Fig. 1), which could be explained as the N1 treatment $(7 \mathrm{mM})$ was not a severe $\mathrm{N}$ deficiency condition for cucumber growth (Dong et al. 2017). In addition, as an indicator of leaf thickness and toughness, we found that the SLW showed a $23.9 \%$ increase in N3 treatment by $\mathrm{eCO}_{2}$ and a $17.5 \%$ increase under $\mathrm{eCO}_{2}$ condition by raising the $\mathrm{N}$ supply from 7 to $21 \mathrm{mM}$. These results were related to the thickening of the leaf cell walls and the enhanced allocation of structural material per unit area of leaves under higher $\mathrm{N}$ and $\mathrm{eCO}_{2}$ condition (Conroy et al. 1992; Pritchard et al. 1999). 


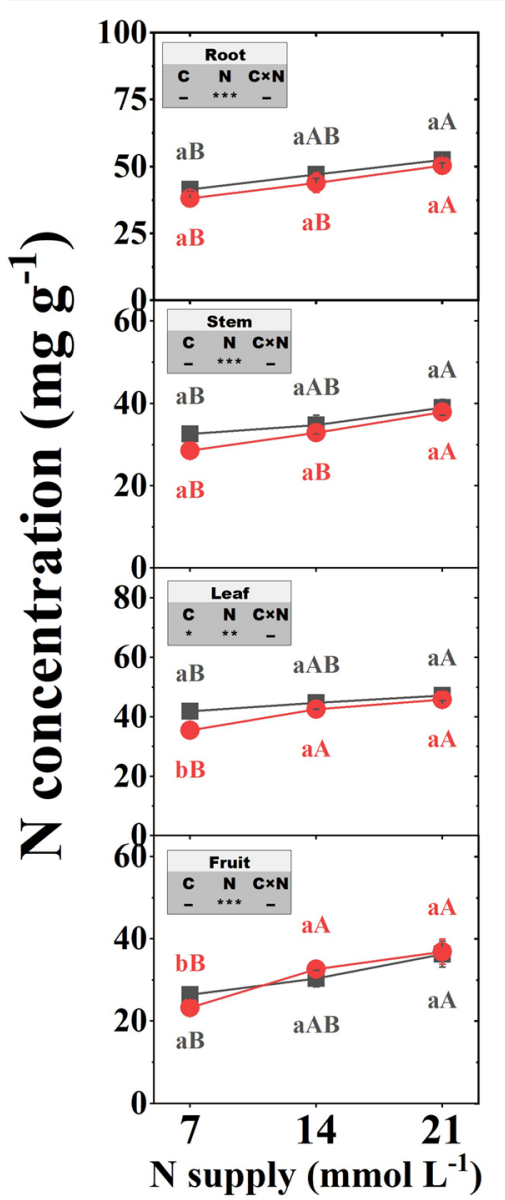

Fig. 6 The nitrogen, phosphorus, and potassium concentrations in roots, stems, leaves, and fruits of cucumber plants grown under different $\mathrm{CO}_{2}$ and $\mathrm{N}$ levels $(n=4)$. Bars represent standard errors. $\mathrm{CO}_{2}$ levels: $\mathrm{C} 1,400 \mu \mathrm{mol} \cdot \mathrm{mol}^{-1} ; \mathrm{C} 2,800 \mu \mathrm{mol} \cdot \mathrm{mol}^{-1}$. Means not followed by the same lower case letters are significantly different among different $\mathrm{CO}_{2}$ levels in the same $\mathrm{N}$ level, and not followed

It is worth noting that the $\mathrm{Tr}$ per plant was larger under $\mathrm{eCO}_{2}$ than that under $\mathrm{aCO}_{2}$ in $\mathrm{N} 2$ and $\mathrm{N} 3$ supply treatments, and it increased with increasing $\mathrm{N}$ supply under $\mathrm{eCO}_{2}$, although the $\mathrm{Tr}$ was significantly inhibited by $\mathrm{eCO}_{2}$ (Fig. 2). Therefore, the higher Tr per plant under $\mathrm{eCO}_{2}$ in moderate and high $\mathrm{N}$ levels was likely the result of increased leaf area per plant, which ultimately offsets the lower $\operatorname{Tr}$ under $\mathrm{eCO}_{2}$ (Wei et al. 2018; $\mathrm{Yi}$ et al. 2020). Moreover, the lower Tr per plant in N1 compared with that in $\mathrm{N} 2$ and N3 treatments would be ascribed to the smaller leaf area of the cucumber plants in low $\mathrm{N}$ conditions (Wei et al. 2018). The highly positive correlation between the water consumption and $\mathrm{Tr}$ per plant in the whole experimental period (Fig. 7) further indicated that $\operatorname{Tr}$ per plant was a good indicator for water usage status at the plant level.

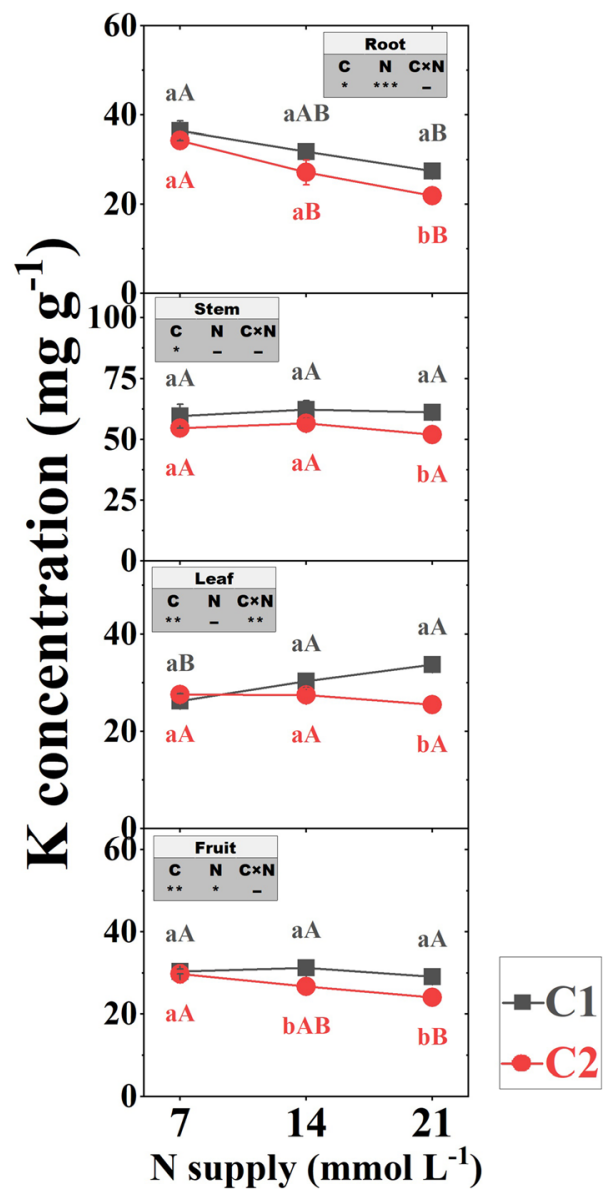

by the same upper case letters are significantly different among different $\mathrm{N}$ levels in the same $\mathrm{CO}_{2}$ level, according to Fisher LSD test at $p<0.05$. In the internal table, $\mathrm{C}, \mathrm{CO}_{2}$ level; $\mathrm{N}, \mathrm{N}$ level. Asterisks $(*)$ indicate significant differences $(* p<0.05$; $* * p<0.01 ; * * * p<0.001)$; Hyphen (-) indicates non-significant differences $(p \geq 0.05)$

As shown in Fig. S3, the accumulations of N, P, and $\mathrm{K}$ in plants were all smaller than their consumption from the nutrient solution. The main reason was that the amounts of $\mathrm{N}, \mathrm{P}$, and $\mathrm{K}$ in the leaf litter (i.e., leaves that had withered) were not included in the accumulation calculation. Besides, some $\mathrm{N}$ may be lost through denitrification from the nutrient solution or lost as $\mathrm{NH}_{3}$ from stomata in leaves. So, we could find a more considerable loss in $\mathrm{N}$ than that in $\mathrm{P}$ or $\mathrm{K}$.

Although the loss of $\mathrm{N}, \mathrm{P}$, and $\mathrm{K}$ existed, the spots presenting the observed values under different $\mathrm{eCO}_{2}$ and $\mathrm{N}$ levels were all near the fit line, which means the loss was almost the same among different treatments. Moreover, the highly positive correlation $\left(\mathrm{R}^{2}=\right.$ 0.867 0.937) between mineral element accumulations per plant and the corresponding consumption from the 

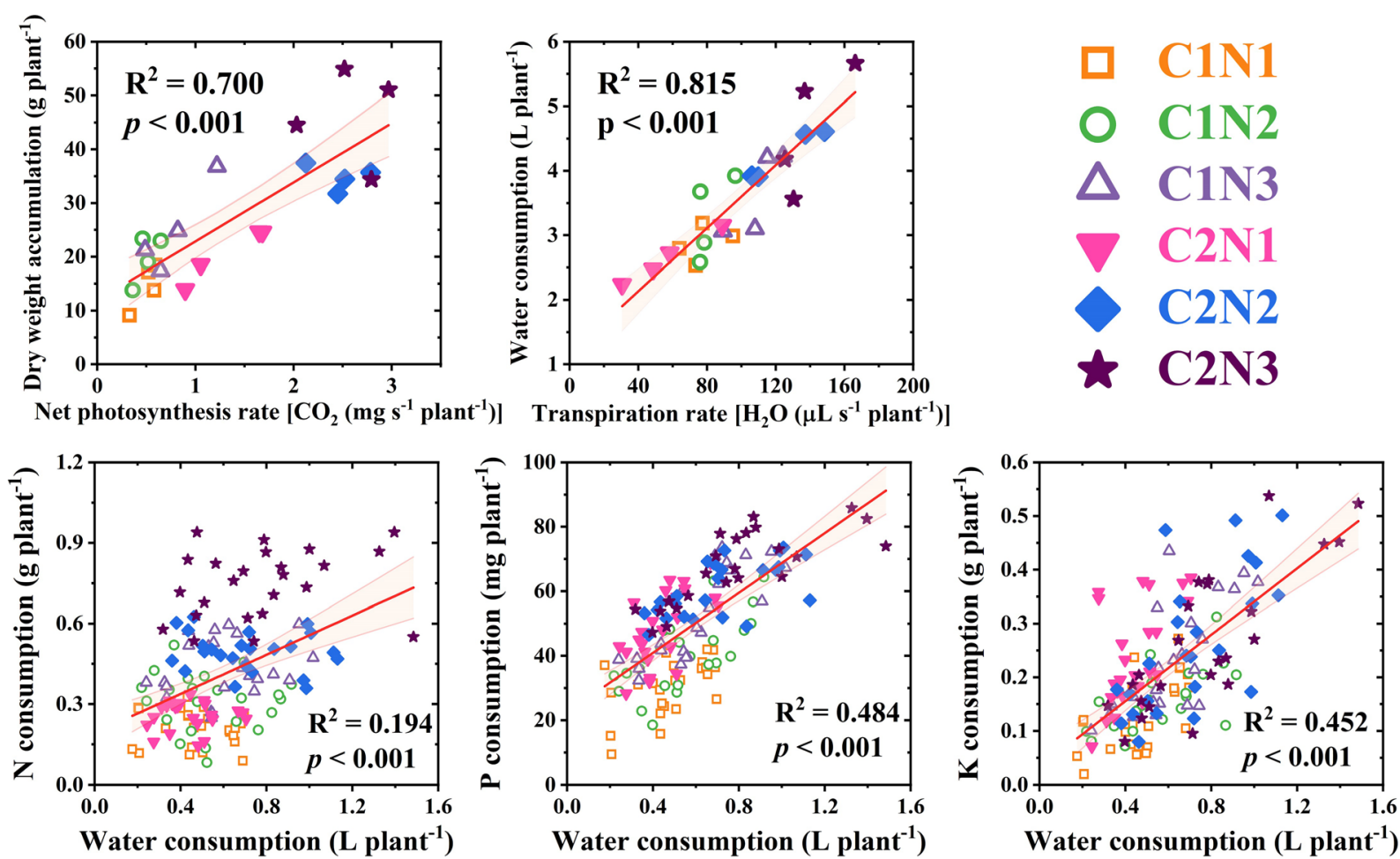

Fig. 7 The relationship between the biomass accumulation and photosynthesis rate per plant; the water consumption and transpiration rate per plant in the whole experimental period; the nitrogen, phosphorus, and potassium consumptions per plant from the nutrient solution, and the corresponding water consumption in each

nutrient solution further indicated that the nutrient consumption was a good indicator for the nutrient accumulation at the plant level.

\section{Nitrogen concentrations in plants}

A decrease in $[\mathrm{N}]$ in plants under $\mathrm{eCO}_{2}$ condition is frequently reported, and the decrease also strongly depends on the N supply levels (Gifford et al. 2000; Pettersson and McDonald 1994). Usually, the decrease in $[\mathrm{N}]$ by $\mathrm{eCO}_{2}$ is more dramatic in N-deficient plants yet is mostly alleviated in N-replete plants (Rogers et al. 1994; Stitt and Krapp 1999). Moreover, it has been reviewed that the average $[\mathrm{N}]$ decrease in leaves $(16 \%)$ is larger than those in stems (9\%) and roots (9\%) (Cotrufo et al. 1998; Sardans et al. 2012). In the present study, $\mathrm{eCO}_{2}$ significantly decreased $[\mathrm{N}]$ in leaves and fruits in plants that received low $\mathrm{N}$ supply (Fig. 6), which coincided with the findings mentioned above. To interpret the reduction of $[\mathrm{N}]$ in plants by $\mathrm{eCO}_{2}$, the dilution effect due to the accumulation of non- nutrient solution round, respectively. $\mathrm{CO}_{2}$ levels: $\mathrm{C} 1$, $400 \mu \mathrm{mol} \cdot \mathrm{mol}^{-1} ; \mathrm{C} 2,800 \mu \mathrm{mol} \cdot \mathrm{mol}^{-1}$. N levels: N1, $7 \mathrm{mmol} \mathrm{L}{ }^{-1}$; N2, $14 \mathrm{mmol} \mathrm{L}^{-1}$; N3, $21 \mathrm{mmol} \mathrm{L}^{-1}$. Shaded area around the curves represents $95 \%$ confidence intervals

structural carbohydrates and the reduced mass flow and root-to-shoot translocation due to decreased transpiration are two well-documented mechanisms (Gifford et al. 2000; McDonald et al. 2002; McGrath and Lobell 2013). In this study, $\mathrm{eCO}_{2}$ increased the total $\mathrm{DW}$ by $39.6 \%$ (n.s.), $76.2 \%$, and $84.3 \%$ (Fig. 1) and increased the $\mathrm{N}$ accumulation by $23.1 \%$ (n.s.), $78.0 \%$, and $79.8 \%$ (Fig. S2) in N1, N2, and N3 supply, respectively. Therefore, the decrease of $[\mathrm{N}]$ in plants with low $\mathrm{N}$ supply by $\mathrm{eCO}_{2}$ could be interpreted by the dilution effect. Although $\mathrm{eCO}_{2}$ significantly inhibited the Tr in $\mathrm{N} 1$ and N2 treatments, only $[\mathrm{N}]$ in plants in $\mathrm{N} 1$ was significantly decreased. It indicated that decreased transpirationdriven mass flow was not a key factor affecting $[\mathrm{N}]$ in plants grown in hydroponic culture, in which $\mathrm{N}$ could reach the root surface more easily than in soil culture (Conroy 1992; Vessey et al. 1990). It has also been suggested that the increase in $\mathrm{N}$ loss is responsible for reducting $[\mathrm{N}]$ in plants by $\mathrm{eCO}_{2}$ (Pang et al. 2006). However, we found little difference between the ratios of the $\mathrm{N}$ accumulation and the $\mathrm{N}$ consumption from the 
nutrient solution per plant in two $\left[\mathrm{CO}_{2}\right]$ conditions (Fig. $\mathrm{S} 3$ ), which means the $\mathrm{N}$ loss was almost the same under different $\left[\mathrm{CO}_{2}\right]$ levels in this study.

In the present work, we aimed to assess the contribution of the short-term fluctuation of $[\mathrm{N}]$ in the nutrient solution on $[\mathrm{N}]$ in cucumber plants. In low $\mathrm{N}$ supply, $\mathrm{eCO}_{2}$ decreased the $\mathrm{Tr}$ per plant by $24.2 \%$ (n.s.) (Fig. 2), but slightly increased the $\mathrm{N}$ consumption per unit water consumption (Fig. 7), which resulted in a much lower $[\mathrm{N}]$ in the nutrient solution (less than $4 \mathrm{mM}$ ) (Fig. 3). Although the increase of $24.1 \%$ in $\mathrm{N}$ consumption and the decrease of $7.9 \%$ in water consumption in the whole experimental period were not significant (Fig. 5), it also gave a piece of evidence that $\mathrm{eCO}_{2}$ significantly decreased $[\mathrm{N}]$ in the low $\mathrm{N}$ nutrient solution, which aggravated the $[\mathrm{N}]$ decrease in plants. In high $\mathrm{N}$ supply, $\mathrm{eCO}_{2}$ increased the $\operatorname{Tr}$ per plant by $39.7 \%$ (n.s.) (Fig. 2) and increased the $\mathrm{N}$ consumption per unit water consumption (Fig. 7), so $[\mathrm{N}]$ in the nutrient solution was also lower under $\mathrm{eCO}_{2}$ than that under $\mathrm{aCO}_{2}$. However, the final $[\mathrm{N}]$ in the nutrient solution was more than $7 \mathrm{mM}$ (Fig. 3), which could still meet the requirements of plants and ensure the regular $[\mathrm{N}]$ in plants (Dai et al. 2011). In addition, we found that an increase of $72.9 \%$ in $\mathrm{N}$ consumption kept pace with an increase of $84.3 \%$ in total DW by e $\mathrm{CO}_{2}$ in the whole experimental period (Fig. 5). It confirms that high $\mathrm{N}$ supply could maintain the adequate $[\mathrm{N}]$ in the nutrient solution and compensate for the decrease of $[\mathrm{N}]$ in plants by dilution effect. Additionally, when $\mathrm{N}$ supply was elevated from 7 to $21 \mathrm{mM}$, the $\mathrm{N}$ consumption was respectively increased by $106.9 \%$ and $188.1 \%$ under $\mathrm{eCO}_{2}$ and $\mathrm{aCO}_{2}$ (Fig. 5), which was more than the increase in total DW $(71.6 \%$ and $126.6 \%$ ). Conceivably, $[\mathrm{N}]$ in plants was significantly increased with the $\mathrm{N}$ supply increasing regardless of $\left[\mathrm{CO}_{2}\right]$.

Phosphorus concentrations in plants

According to a meta-analysis with 2024 records from 112 published articles, an average decrease of $4.0 \%$ in $[\mathrm{P}]$ in plants by $\mathrm{eCO}_{2}$ was found, which was much less than the decrease of [N] (12.7\%) (Deng et al. 2015). In a similar meta-analysis, under $\mathrm{eCO}_{2}$, the leaf $\mathrm{C}: \mathrm{P}$ ratios in 19 out of 32 species studied were significantly increased, the ratios in five species were significantly decreased, and the ratios in eight species were not significantly affected (Sardans et al. 2012). The uncertainty in the feedbacks of $[\mathrm{P}]$ change in plants on $\mathrm{eCO}_{2}$ mainly stems from the competition between the dilution effect and the increased metabolic demand for P (Conroy 1992; Gifford et al. 2000). In the present work, besides the dilution effect and the P demand, the effects of the short-term fluctuation of $[\mathrm{P}]$ in the nutrient solution on $[\mathrm{P}]$ in plants were also evaluated.

In low $\mathrm{N}$ supply, $\mathrm{eCO}_{2}$ increased $\mathrm{P}$ requirement for the phosphorylated photosynthetic intermediates and the intercellular transport (Gifford et al. 2000; Jin et al. 2015). Meanwhile, the Tr per plant was slightly decreased by $\mathrm{eCO}_{2}$ (Fig. 2), so we found a significant increase of the $\mathrm{P}$ consumption per unit water consumption under $\mathrm{eCO}_{2}$ (Fig. 7). Accordingly, $[\mathrm{P}]$ in the residual nutrient solution was significantly lower under $\mathrm{eCO}_{2}$ than that under $\mathrm{eCO}_{2}$ (Fig. 4) but was still above the $0.6 \mathrm{mM}$ level and sufficient for the cucumber growth (Halbert-Howard et al. 2020; Neocleous and Savvas 2015). Under $\mathrm{eCO}_{2}$ condition, $\mathrm{P}$ consumption and total DW increments were $60.4 \%$ and $39.6 \%$ (n.s.), respectively (Figs. 1 and 5). It indicated that the increase in P requirement by $\mathrm{eCO}_{2}$ was more extensive than that in DW accumulation, which resulted in an increase of [P] in stems and fruits of cucumber plants (Fig. 6). In high $\mathrm{N}$ supply, $\mathrm{eCO}_{2}$ increased both $\mathrm{Tr}$ per plant and $\mathrm{P}$ requirement, which made a synchronous increase in water and $\mathrm{P}$ uptakes (Fig. 7). The total water and $\mathrm{P}$ consumptions were increased by $27.6 \%$ and $27.2 \%$ (Fig. 5), respectively, leading to an undifferentiated $[\mathrm{P}]$ in the residual nutrient solution at the later growth stage (Fig. 4). Therefore, the decrease or the trend of decrease in $[\mathrm{P}]$ in cucumber plants was mainly caused by the increase of total DW accumulation (+84.3\%), which was dramatically promoted by $\mathrm{eCO}_{2}$ coupled with high $\mathrm{N}$ supply (Jarrell and Beverly 1981).

Similar to $\mathrm{eCO}_{2}$, increasing the $\mathrm{N}$ supply could also improve the DW accumulation and cause a dilution effect on other mineral element concentrations in plants when the supplies of other mineral elements were not increased accordingly (Halpern et al. 2019; Lenka et al. 2019; Papadopoulos 1986). In the present study, [P] in cucumber plants was significantly decreased with the $\mathrm{N}$ supply increasing only under $\mathrm{eCO}_{2}$ conditions, which indicated other factors rather than dilution effect involved in the changes of $[\mathrm{P}]$ in plants. Under $\mathrm{aCO}_{2}$ conditions, we found a greater $\mathrm{P}$ consumption per unit water consumption in high $\mathrm{N}$ supply than that in low $\mathrm{N}$ supply (Fig. 7), which may be due to the improved root growth and higher root activity in high $\mathrm{N}$ supply (Leonce and Miller 1966). Therefore, the increment of 
P consumption was $73.7 \%$ when the $\mathrm{N}$ supply was elevated from $\mathrm{N} 1$ to $\mathrm{N} 3$, which was equivalent to the increment of total DW (+71.6\%) (Figs. 1 and 5). Thus, $[\mathrm{P}]$ in cucumber plants stably maintained in different $\mathrm{N}$ supply levels (Fig. 6). Under $\mathrm{eCO}_{2}$ conditions, both $\mathrm{Tr}$ per plant and $\mathrm{P}$ requirement were increased with the $\mathrm{N}$ supply increasing, so the $\mathrm{P}$ consumption per unit water consumption has little difference (Fig. 7). Therefore, the significant decrease of $[\mathrm{P}]$ in cucumber plants with the $\mathrm{N}$ supply increasing was mainly caused by the larger increment of total DW $(+126.6 \%)$ than that of P consumption $(+37.8 \%)$ (Figs. 1 and 5) (Halpern et al. 2019; Jarrell and Beverly 1981).

\section{Potassium concentrations in plants}

The current study showed that $[\mathrm{K}]$ in cucumber plants was $16.3 \%$ lower in high $\mathrm{N}$ supply under $\mathrm{eCO}_{2}$ than that under $\mathrm{aCO}_{2}$ condition (Fig. 6), which was larger than the average $[\mathrm{K}]$ decrease of $10 \%$ by $\mathrm{eCO}_{2}$ in previous reviews (Loladze 2002; McGrath and Lobell 2013). It has been frequently suggested that the decrease of $[\mathrm{K}]$ in plants by $\mathrm{eCO}_{2}$ was mainly caused by the biomass dilution (Fernando et al. 2014; Halpern et al. 2019; Zhu et al. 2016). However, the differences in [K] in plants between two $\left[\mathrm{CO}_{2}\right]$ conditions in low $\mathrm{N}$ supply were slight (Fig. 6), so there must be other factors in addition to dilution effect involved in the decrease of $[\mathrm{K}]$ in plants by $\mathrm{eCO}_{2}$. In this work, we focused on the short-term fluctuation of $[\mathrm{K}]$ in the nutrient solution.

In low $\mathrm{N}$ supply, $\mathrm{eCO}_{2}$ had little effect on the Tr per plant (Fig. 2). Although the $\mathrm{K}$ consumption per unit water consumption was increased by $\mathrm{eCO}_{2}$ (Fig. 7), the differences in $[\mathrm{K}]$ in the residual nutrient solution between two $\left[\mathrm{CO}_{2}\right]$ conditions were not significant, and the final $[\mathrm{K}]$ was more than $5 \mathrm{mM}$. The adequate and stable $[\mathrm{K}]$ in the nutrient solution afforded the increase of $\mathrm{K}$ consumption by $(+47.6 \%$, n.s.) (Fig. 5), which was parallel to the increase of total DW accumulation $(+39.6 \%$, n.s.). Thus, $[\mathrm{K}]$ in all parts of cucumber plants did not change by $\mathrm{eCO}_{2}$ (Fig. 6). In high $\mathrm{N}$ supply, the Tr per plant had an increasing trend by $\mathrm{eCO}_{2}$ (Fig. 2), and the $\mathrm{K}$ consumption per unit water consumption was moderately increased (Fig. 7). Therefore, increment in K consumption $(+65.1 \%)$ in the whole experimental period was larger than that in total water consumption $(+27.6 \%)$ (Fig. 5), resulting in a steep decline in $[\mathrm{K}]$ in the residual nutrient solution, especially at the later growth stage (Fig. 4). The final $[\mathrm{K}]$ in the nutrient solution was about $3 \mathrm{mM}$, only a half of the initial value, which severely aggravated the $[\mathrm{K}]$ decline in plants under $\mathrm{eCO}_{2}$ (Halbert-Howard et al. 2020; Neocleous and Savvas 2015; Savvas et al. 2014). Moreover, the increase in total DW accumulation by $\mathrm{eCO}_{2}(84.3 \%)$ outstripped that in $\mathrm{K}$ consumption $(+65.1 \%)$, which indicated that the decrease of $[\mathrm{K}]$ in all parts of cucumber plants by $\mathrm{eCO}_{2}$ was inevitable (Fig. 6).

Meanwhile, $\mathrm{N}$ supply also exerted a significant impact on $[\mathrm{K}]$ in cucumber plants. Under $\mathrm{aCO}_{2}$ conditions, although increasing the $\mathrm{N}$ supply promoted the $\mathrm{K}$ consumption per unit water consumption and decreased $[\mathrm{K}]$ in the residual nutrient solution (Figs. 4 and 7), $[\mathrm{K}]$ in the nutrient solution (more than $5 \mathrm{mM}$ ) could afford the cucumber growth. Therefore, the decrease of $[\mathrm{K}]$ in roots and increase of $[\mathrm{K}]$ in leaves with $\mathrm{N}$ supply increasing were mainly caused by the synchronous uptake of $\mathrm{K}^{+}$with $\mathrm{NO}_{3}{ }^{-}$(Li et al. 2020; Zhang et al. 2010). Previous studies showed that $\mathrm{K}^{+}$was always transported in xylem sap accompanied by $\mathrm{NO}_{3}{ }^{-}$from roots to shoots to maintain the balance between anions and cations (Blevins et al. 1978; Triplett et al. 1980). Under $\mathrm{eCO}_{2}$ conditions, the uptake of $\mathrm{K}^{+}$was significantly increased with increasing $\mathrm{N}$ supply due to the synchronous uptake of $\mathrm{K}^{+}$with $\mathrm{NO}_{3}{ }^{-}$. It was evidenced by the synchronized increment of consumptions of $\mathrm{K}(+122.7 \%)$ and $\mathrm{N}$ $(+188.1 \%)$ when the $\mathrm{N}$ supply was increased from 7 to $21 \mathrm{mM}$, whereas the corresponding increment of water consumption was only $75.9 \%$ (Fig. 5). Therefore, increasing the $\mathrm{N}$ supply enormously decreased $[\mathrm{K}]$ in the residual nutrient solution, especially at the later growth stage, and the decrease of $[\mathrm{K}]$ fluctuated from 25.1 to $41.2 \%$ (Fig. 4). The deficiency of $\mathrm{K}$ in the nutrient solution severely inhibited the further uptake of $\mathrm{K}^{+}$, leading a significant decrease of $[\mathrm{K}]$ in roots and fruits of cucumber plants when the $\mathrm{N}$ supply was increased from 7 to $21 \mathrm{mM}$ (Fig. 6).

\section{Conclusions}

In the present study, we found $\mathrm{eCO}_{2}$ inhibited the $\mathrm{Tr}$ per plant increment but improved the $\mathrm{N}$ consumption in low $\mathrm{N}$ treatment. Therefore, $[\mathrm{N}]$ in the nutrient solution in the closed hydroponic system decreased significantly too far below the demand of cucumber plants, which imposed an additional $[\mathrm{N}]$ decrease in plants besides the dilution effect by $\mathrm{eCO}_{2}$. [P] in the nutrient solution slightly fluctuated during one round of nutrient solution 
treatment and was always abundant for the cucumber growth regardless of the $\left[\mathrm{CO}_{2}\right]$ and $\mathrm{N}$ supply levels, so the change of $[\mathrm{P}]$ in the cucumber plants was mainly attributed to the dilution effect and the demand change. [K] in the nutrient solution decreased significantly in moderate and high $\mathrm{N}$ treatments due to the synchronous uptake of $\mathrm{K}^{+}$with $\mathrm{NO}_{3}{ }^{-}$, which would exacerbate the $[\mathrm{K}]$ decrease in plants under $\mathrm{eCO}_{2}$.

Back to our hypothesis posed at the beginning, it is safe to state that the asynchronous change in the uptake of $\mathrm{N}, \mathrm{K}$, and water under $\mathrm{eCO}_{2}$ compared with that under $\mathrm{aCO}_{2}$ results in a short-term fluctuation of $[\mathrm{N}]$ and $[\mathrm{K}]$ in the nutrient solution in the commonly used closed hydroponic systems. Moreover, this fluctuation of nutrient concentrations due to the defect of experimental set-ups could lead to an appreciable decline of $[\mathrm{N}]$ and $[\mathrm{K}]$ in plants, which may let us exaggerate the negative impact of $\mathrm{eCO}_{2}$ itself. It is recommended to renew the nutrient solution as frequently as possible, to eliminate the influence of nutrient fluctuation in solutions on the plant nutritional status and distinguish the real effects of $\mathrm{eCO}_{2}$. Savvas and Adamidis (1999), and Zheng et al. (2010) also suggested using bigger growth containers or continuously flowing nutrient solution with constant elemental concentrations controlled by automated systems. Furthermore, a practical implication is that the improved nutrient solution formulations based on the nutrient requirements of plants under $\mathrm{eCO}_{2}$ condition are urgently needed for the greenhouse vegetable production with $\mathrm{eCO}_{2}$ fertilization or for the field crop production in future climate scenarios. An appropriate increase in $\mathrm{N}$ and $\mathrm{K}$ supply is recommended under $\mathrm{eCO}_{2}$ condition in the present study. Thus, the sustainable crop production avoiding photosynthetic acclimation and utilizing the benefits of $\mathrm{eCO}_{2}$ could be achieved in future climate change scenarios (Gruda et al. 2019a, b).

Supplementary Information The online version contains supplementary material available at https://doi.org/10.1007/s11104021-04993-y.

Funding Open Access funding enabled and organized by Projekt DEAL. The authors thank the National Natural Science Foundation of China (41877103), the Strategic Priority Research Program of the Chinese Academy of Science (XDA23020401), the Natural Science Foundation of Jiangsu Province in China (BK2018402), and the Frontier Project of Knowledge Innovation Program of Institute of Soil Science, Chinese Academy of Sciences (ISSASIP1635) for funding support.
Open Access This article is licensed under a Creative Commons Attribution 4.0 International License, which permits use, sharing, adaptation, distribution and reproduction in any medium or format, as long as you give appropriate credit to the original author(s) and the source, provide a link to the Creative Commons licence, and indicate if changes were made. The images or other third party material in this article are included in the article's Creative Commons licence, unless indicated otherwise in a credit line to the material. If material is not included in the article's Creative Commons licence and your intended use is not permitted by statutory regulation or exceeds the permitted use, you will need to obtain permission directly from the copyright holder. To view a copy of this licence, visit http://creativecommons.org/licenses/by/4.0/.

\section{References}

Agüera E, De la Haba P (2018) Leaf senescence in response to elevated atmospheric $\mathrm{CO}_{2}$ concentration and low nitrogen supply. Biol Plant 62:401-408

Amann C, Amberger A (1989) Phosphorus efficiency of buckwheat (Fagopyrum-Esculentum). J Plant Nutr Soil Sci 152: 181-189

Asensio JS, Rachmilevitch S, Bloom AJ (2015) Responses of arabidopsis and wheat to rising $\mathrm{CO}_{2}$ depend on nitrogen source and nighttime $\mathrm{CO}_{2}$ levels. Plant Physiol 168:156-163

Blevins DG, Barnett NM, Frost WB (1978) Role of potassium and malate in nitrate uptake and translocation by wheat seedlings. Plant Physiol 62:784-788

Bloom AJ, Burger M, Rubio Asensio JS, Cousins AB (2010) Carbon dioxide enrichment inhibits nitrate assimilation in wheat and Arabidopsis. Science 328:899-903

Conroy JP (1992) Influence of elevated atmospheric $\mathrm{CO}_{2}$ concentrations on plant nutrition. Aust J Bot 40:445-456

Conroy JP, Milham PJ, Barlow EWR (1992) Effect of nitrogen and phosphorus availability on the growth response of Eucalyptus grandis to high $\mathrm{CO}_{2}$. Plant Cell Environ 15: 843-847

Cotrufo MF, Ineson P, Scott A (1998) Elevated $\mathrm{CO}_{2}$ reduces the nitrogen concentration of plant tissues. Glob Chang Biol 4: 43-54

Dai J, Liu S, Zhang W, Xu R, Luo W, Zhang S, Yin X, Han L, Chen W (2011) Quantifying the effects of nitrogen on fruit growth and yield of cucumber crop in greenhouses. Sci Hortic 130:551-561

Deng Q, Hui D, Luo Y, Elser J, Wang YP, Loladze I, Zhang Q, Dennis S (2015) Down-regulation of tissue N:P ratios in terrestrial plants by elevated $\mathrm{CO}_{2}$. Ecology 96:3354-3362

Dong J, Li X, Chu W, Duan Z (2017) High nitrate supply promotes nitrate assimilation and alleviates photosynthetic acclimation of cucumber plants under elevated $\mathrm{CO}_{2}$. Sci Hortic 218:275-283

Dong J, Gruda N, Lam SK, Li X, Duan Z (2018) Effects of elevated $\mathrm{CO}_{2}$ on nutritional quality of vegetables: a review. Front Plant Sci 9:924

Fernando N, Panozzo J, Tausz M, Norton RM, Neumann N, Fitzgerald GJ, Seneweera S (2014) Elevated $\mathrm{CO}_{2}$ alters grain quality of two bread wheat cultivars grown under different environmental conditions. Agric Ecosyst Environ 185:24-33 
Gifford RM, Barrett DJ, Lutze JL (2000) The effects of elevated $\left[\mathrm{CO}_{2}\right]$ on the $\mathrm{C}: \mathrm{N}$ and $\mathrm{C}: \mathrm{P}$ mass ratios of plant tissues. Plant Soil 224:1-14

Gruda NS (2019) Increasing sustainability of growing media constituents and stand-alone substrates in soilless culture systems. Agronomy 9:298

Gruda N, Bisbis M, Tanny J (2019a) Impacts of protected vegetable cultivation on climate change and adaptation strategies for cleaner production - a review. J Clean Prod 225:324-339

Gruda N, Bisbis M, Tanny J (2019b) Influence of climate change on protected cultivation: impacts and sustainable adaptation strategies - a review. J Clean Prod 225:481-495

Halbert-Howard A, Hafner F, Karlowsky S, Schwarz D, Krause A (2020) Evaluating recycling fertilizers for tomato cultivation in hydroponics, and their impact on greenhouse gas emissions. Environ Sci Pollut Res Int. https://doi.org/10.1007 /s11356-11020-10461-11354

Halpern M, Bar-Tal A, Lugassi N, Egbaria A, Granot D, Yermiyahu U (2019) The role of nitrogen in photosynthetic acclimation to elevated $\left[\mathrm{CO}_{2}\right]$ in tomatoes. Plant Soil 434: $397-411$

Hoagland DR, Arnon DI (1938) The water culture method for growing plants without soil. UC College of Agriculture, Ag Exp Station, Berkeley, CA. Circular 347:1-39

Houshmandfar A, Fitzgerald GJ, O'Leary G, Tausz-Posch S, Fletcher A, Tausz M (2018) The relationship between transpiration and nutrient uptake in wheat changes under elevated atmospheric $\mathrm{CO}_{2}$. Physiol Plant 163:516-529

Jarrell WM, Beverly RB (1981) The dilution effect in plant nutrition studies. Adv Agron 34:197-224

Jauregui I, Aparicio-Tejo PM, Baroja E, Avila C, Aranjuelo I (2017) Elevated $\mathrm{CO}_{2}$ improved the growth of a double nitrate reductase defective mutant of Arabidopsis thaliana: the importance of maintaining a high energy status. Environ Exp Bot 140:110-119

Jin J, Tang C, Sale P (2015) The impact of elevated carbon dioxide on the phosphorus nutrition of plants: a review. Ann Bot 116: 987-999

Jin J, Armstrong R, Tang C (2019) Impact of elevated $\mathrm{CO}_{2}$ on grain nutrient concentration varies with crops and soils - a long-term FACE study. Sci Total Environ 651:2641-2647

Kläring HP, Hauschild C, Heißner A, Bar-Yosef B (2007) Modelbased control of $\mathrm{CO}_{2}$ concentration in greenhouses at ambient levels increases cucumber yield. Agric For Meteorol 143: 208-216

Lambers H, Raven JA, Shaver GR, Smith SE (2008) Plant nutrient-acquisition strategies change with soil age. Trends Ecol Evol 23:95-103

Lawlor DW, Mitchell RAC (1991) The effects of increasing $\mathrm{CO}_{2}$ on crop photosynthesis and productivity: a review of field studies. Plant Cell Environ 14:807-818

Lenka NK, Lenka S, Singh KK, Kumar A, Aher SB, Yashona DS, Dey P, Agrawal PK, Biswas AK, Patra AK (2019) Effect of elevated carbon dioxide on growth, nutrient partitioning, and uptake of major nutrients by soybean under varied nitrogen application levels. J Plant Nutr Soil Sci 182:509-514

Leonce FS, Miller MH (1966) A physiological effect of nitrogen on phosphorus absorption by corn. Agron J 58:245-249

Li X, Dong J, Chu W, Chen Y, Duan Z (2018) The relationship between root exudation properties and root morphological traits of cucumber grown under different nitrogen supplies and atmospheric $\mathrm{CO}_{2}$ concentrations. Plant Soil 425:415432

Li S, Li Y, He X, Li Q, Liu B, Ai X, Zhang D (2019) Response of water balance and nitrogen assimilation in cucumber seedlings to $\mathrm{CO}_{2}$ enrichment and salt stress. Plant Physiol Biochem 139:256-263

Li X, Dong J, Gruda NS, Chu W, Duan Z (2020) Interactive effects of the $\mathrm{CO}_{2}$ enrichment and nitrogen supply on the biomass accumulation, gas exchange properties, and mineral elements concentrations in cucumber plants at different growth stages. Agronomy 10:139

Loladze I (2002) Rising atmospheric $\mathrm{CO}_{2}$ and human nutrition: toward globally imbalanced plant stoichiometry? Trends Ecol Evol 17:457-461

Ma Q, Wang J, Sun Y, Yang X, Ma J, Li T, Wu L (2018) Elevated $\mathrm{CO}_{2}$ levels enhance the uptake and metabolism of organic nitrogen. Physiol Plant 162:467-478

McDonald EP, Erickson JE, Kruger EL (2002) Can decreased transpiration limit plant nitrogen acquisition in elevated $\mathrm{CO}_{2}$ ? Funct Plant Biol 29:1115-1120

McGrath JM, Lobell DB (2013) Reduction of transpiration and altered nutrient allocation contribute to nutrient decline of crops grown in elevated $\mathrm{CO}_{2}$ concentrations. Plant Cell Environ 36:697-705

Meinshausen M, Smith SJ, Calvin K, Daniel JS, Kainuma MLT, Lamarque JF, Matsumoto K, Montzka SA, Raper SCB, Riahi K, Thomson A, Velders GJM, van Vuuren DPP (2011) The RCP greenhouse gas concentrations and their extensions from 1765 to 2300. Clim Chang 109:213-241

National Oceanic and Atmospheric Administration (NOAA) (2020) Earth System Research Laboratory. http://www.esrl. noaa.gov/gmd/ccgg/trends/global.html

Neocleous D, Savvas D (2015) Effect of different macronutrient cation ratios on macronutrient and water uptake by melon (Cucumis melo) grown in recirculating nutrient solution. J Plant Nutr Soil Sci 178:320-332

Niu Y, Chai R, Dong H, Wang H, Tang C, Zhang Y (2013) Effect of elevated $\mathrm{CO}_{2}$ on phosphorus nutrition of phosphatedeficient Arabidopsis thaliana (L.) Heynh under different nitrogen forms. J Exp Bot 64:355-367

Pang J, Zhu J-G, Xie Z-B, Liu G, Zhang Y-L, Chen G-P, Zeng Q, Cheng L (2006) A new explanation of the $\mathrm{N}$ concentration decrease in tissues of rice (Oryza sativa L.) exposed to elevated atmospheric $p \mathrm{CO}_{2}$. Environ Exp Bot 57:98-105

Papadopoulos I (1986) Nitrogen fertigation of greenhouse-grown cucumber. Plant Soil 93:87-93

Peet MM (1986) Acclimation to high $\mathrm{CO}_{2}$ in monoecious cucumbers .1. vegetative and reproductive growth. Plant Physiol 80: $59-62$

Pettersson R, McDonald AJ (1994) Effects of nitrogen supply on the acclimation of photosynthesis to elevated $\mathrm{CO}_{2}$. Photosynth Res 39:389-400

Pritchard SG, Rogers HH, Prior SA, Peterson CM (1999) Elevated $\mathrm{CO}_{2}$ and plant structure: a review. Glob Chang Biol 5:807837

Reardon J, Foreman JA, Searcy RL (1966) New reactants for the colorimetric determination of ammonia. Clin Chim Acta 14: 403-405

Reich PB, Hungate BA, Luo Y (2006) Carbon-nitrogen interactions in terrestrial ecosystems in response to rising 
atmospheric carbon dioxide. Annu Rev Ecol Evol Syst 37: 611-636

Rodriguez-Hernandez Mdel C, Moreno DA, Carvajal M, Martinez-Ballesta Mdel C (2014) Genotype influences sulfur metabolism in broccoli (Brassica oleracea L.) under elevated $\mathrm{CO}_{2}$ and $\mathrm{NaCl}$ stress. Plant Cell Physiol 55:2047-2059

Rogers HH, Dahlman RC (1993) Crop responses to $\mathrm{CO}_{2}$ enrichment. Vegetatio 104-105:117-131

Rogers GS, Payne L, Milham P, Conroy J (1993) Nitrogen and phosphorus requirements of cotton and wheat under changing atmospheric $\mathrm{CO}_{2}$ concentrations. Plant Soil 155-156: 231-234

Rogers HH, Runion GB, Krupa SV (1994) Plant responses to atmospheric $\mathrm{CO}_{2}$ enrichment with emphasis on roots and the rhizosphere. Environ Pollut 83:155-189

Sanz-Saez A, Erice G, Aranjuelo I, Nogues S, Irigoyen JJ, Sanchez-Diaz M (2010) Photosynthetic down-regulation under elevated $\mathrm{CO}_{2}$ exposure can be prevented by nitrogen supply in nodulated alfalfa. J Plant Physiol 167:1558-1565

Sardans J, Rivas-Ubach A, Peñuelas J (2012) The C:N:P stoichiometry of organisms and ecosystems in a changing world: a review and perspectives. Perspect Plant Ecol 14:33-47

Sardans J, Grau O, Chen HYH, Janssens IA, Ciais P, Piao S, Penuelas J (2017) Changes in nutrient concentrations of leaves and roots in response to global change factors. Glob Chang Biol 23:3849-3856

Savvas D, Adamidis K (1999) Automated management of nutrient solutions based on target electrical conductivity, $\mathrm{pH}$, and nutrient concentration ratios. J Plant Nutr 22:1415-1432

Savvas D, Ntatsi G, Rodopoulou M, Goumenaki F (2014) Nutrient uptake concentrations in a cucumber crop grown in a closed hydroponic system under Mediterranean climatic conditions as influenced by irrigation schedule. Acta Hortic:545-552

Stitt M, Krapp A (1999) The interaction between elevated carbon dioxide and nitrogen nutrition: the physiological and molecular background. Plant Cell Environ 22:583-621

Stulen I, Denhertog J (1993) Root-growth and functioning under atmospheric $\mathrm{CO}_{2}$ enrichment. Vegetatio 104:99-115

Taub DR, Wang X (2008) Why are nitrogen concentrations in plant tissues lower under elevated $\mathrm{CO}_{2}$ ? A critical examination of the hypotheses. J Integr Plant Biol 50:1365-1374

Triplett EW, Barnett NM, Blevins DG (1980) Organic acids and ionic balance in xylem exudate of wheat during nitrate or sulfate absorption. Plant Physiol 65:610-613 van der Kooi CJ, Reich M, Löw M, De Kok LJ, Tausz M (2016) Growth and yield stimulation under elevated $\mathrm{CO}_{2}$ and drought: a meta-analysis on crops. Environ Exp Bot 122: $150-157$

Vessey JK, Henry LT, Raper CD Jr (1990) Nitrogen nutrition and temporal effects of enhanced carbon dioxide on soybean growth. Crop Sci 30:287-294

Vicente R, Perez P, Martinez-Carrasco R, Morcuende R (2017) Improved responses to elevated $\mathrm{CO}_{2}$ in durum wheat at a low nitrate supply associated with the upregulation of photosynthetic genes and the activation of nitrate assimilation. Plant Sci 260:119-128

Wei ZH, Du TS, Li XN, Fang L, Liu FL (2018) Interactive effects of $\mathrm{CO}_{2}$ concentration elevation and nitrogen fertilization on water and nitrogen use efficiency of tomato grown under reduced irrigation regimes. Agric Water Manag 202:174-182

Yamazaki K (1982) Nutrient solution culture. Pak-Kyo Co., Tokyo

Yi Y, Sugiura D, Yano K (2020) Nitrogen and water demands for maximum growth of Solanum tuberosum under doubled $\mathrm{CO}_{2}$ : interaction with phosphorus based on the demands. Environ Exp Bot 176:104089

Yilmaz O, Kahraman K, Ozturk L (2016) Elevated carbon dioxide exacerbates adverse effects of $\mathrm{mg}$ deficiency in durum wheat. Plant Soil 410:41-50

Zhang F, Niu J, Zhang W, Chen X, Li C, Yuan L, Xie J (2010) Potassium nutrition of crops under varied regimes of nitrogen supply. Plant Soil 335:21-34

Zhao F, McGrath SP, Crosland AR (2008) Comparison of three wet digestion methods for the determination of plant sulphur by inductively coupled plasma atomic emission spectroscopy (ICP-AES). Commun Soil Sci Plant Anal 25:407-418

Zheng Y, Cayanan DF, Dixon M (2010) Optimum feeding nutrient solution concentration for greenhouse potted miniature rose production in a recirculating subirrigation system. HortScience 45:1378-1383

Zhu C, Zeng Q, Yu H, Liu S, Dong G, Zhu J (2016) Effect of elevated $\mathrm{CO}_{2}$ on the growth and macronutrient $(\mathrm{N}, \mathrm{P}$ and $\mathrm{K})$ uptake of annual wormwood (Artemisia annua L.). Pedosphere 26:235-242

Publisher's note Springer Nature remains neutral with regard to jurisdictional claims in published maps and institutional affiliations. 